\title{
Entrusted Loans: A Close Look at China's Shadow Banking System*
}

\author{
Franklin Allen \\ Imperial College London \\ f.allen@imperial.ac.uk \\ Yiming Qian \\ The University of Iowa \\ yiming-qian@uiowa.edu \\ Guoqian Tu \\ Chongqing University \\ tuguoqian@cqu.edu.cn \\ Frank Yu \\ China Europe International Business School \\ fyu@ceibs.edu
}

March 22, 2018

\footnotetext{
* We would like to thank Wei Jiang, Andrew Karolyi, Jun Qian, Wei Xiong, Yunqi Zhang, and seminar participants at Bank of Finland, Shanghai Science and Technology University, 2015 Symposium on Emerging Financial Markets, 2015 SAIF/CKGSB Summer Institute of Finance Conference, and 2015 China International Conference in Finance for useful comments. We are particularly grateful to the editor, Toni Whited, and an anonymous referee for their suggestions. All errors are ours. We acknowledge financial support from the National Natural Science Foundation of China (under \#71232004, 71172082, 71172083), the Social Science Foundation of the Ministry of Education of China (14XJC790009), and China Europe International Business School.
} 


\title{
Entrusted Loans: A Close Look at China's Shadow Banking System
}

\begin{abstract}
We perform transaction-level analyses of entrusted loans - one of the largest components of shadow banking in China. Entrusted loans involve firms with privileged access to cheap capital channeling funds to less privileged firms, and increase when credit is tight. Nonaffiliated loans have much higher interest rates than both affiliated loans and official bank loans, and largely flow into real estate. The pricing of entrusted loans - especially of nonaffiliated loansincorporates fundamental and informational risks. Stock market reactions suggest that both affiliated and nonaffiliated loans are fairly compensated investments.
\end{abstract}

JEL Classification: G23, G28

Keywords: shadow banking, entrusted loans, credit shortage, fundamental risk, informational risk 


\section{Introduction}

Shadow banking — credit intermediation involving activities outside the traditional banking system - has undergone tremendous growth worldwide in the last decade. It is particularly prevalent in China. The size of the sector has doubled since 2011 and by the first half of 2016 was equivalent to $82 \%$ of the country's GDP (Moody's report 2017). The phenomenon has generated heated debate on the net benefits of the sector. Regulators are ambivalent on how and to what extent to regulate this sector (see, for example, Wei and Davis, 2014).

We provide a large-sample transaction-level analysis of an important part of China's shadow banking system—entrusted loans. Entrusted loans are loans made by a nonbank party (e.g., an industrial firm) to another, using a bank as a servicing agent. The bank earns a fee for its service but does not bear the investment risk. Entrusted loans were the largest component of the sector until 2014 and are now the second largest, having been surpassed by wealth management products (WMPs). By the first half of 2016, outstanding entrusted loans amounted to 12.1 trillion RMB (1.8 trillion USD). A 2014 Wall Street Journal article described the situation: "Loans between companies is the fastest-growing category of shadow banking in China, but with next to no data on where such loans are going, their effect on the economy is a black box." 1

By examining transaction-level data, we shed light on four general questions about shadow banking: (1) the reasons behind the rise of these activities, (2) the risk of the sector, (3) the pricing efficiency of these transactions, and (4) how shadow banking should be regulated. With regard to the first question, researchers hypothesize that shadow banking arises as a reaction to imperfections and distortions in financial markets. The official financial system in China (consisting of banks and stock and bond markets), after long and gradual reforms, is still not accessible to most private firms, especially small and medium-sized firms (Allen and Qian, 2014, and the references therein). Our study provides evidence on how distorted the system is by

\footnotetext{
${ }^{1}$ McMahon and Wei, “A Partial Primer to China’s Biggest Shadow: Entrusted Loans,” Wall Street Journal, May 2 , 2014.
} 
comparing the interest rate of nonaffiliated entrusted loans and the official bank loans, and how capital flows to firms and industries with restricted access to capital.

The second general question regarding shadow banking is whether these activities will amplify or disseminate systemic risk. How much risk shadow banking adds to the economy and to the financial system depends on two factors. The first is what real investment projects these activities fund and the risk of these. The second is how the activities are financed. We have little systematic evidence concerning these. Most of the discussion is at the theoretical level or based on anecdotal observations. Our study examines the asset side of entrusted loans and the financial structure of the lending firms, and thus provides micro-foundation for the discussion of the riskiness of the sector.

The third issue is pricing efficiency. There is little understanding in the literature about the pricing efficiency of shadow credit. On the one hand, market competition should lead to efficient pricing. On the other hand, alternative lenders may not have the experience and expertise to price the credit efficiently. Our study provides in-depth evidence on this matter as well.

The fourth general question is how shadow banking should be regulated. It is often argued that shadow banking should be restricted or eliminated to ensure financial stability since it often involves avoiding regulation in the formal sector. We show that this view is too simplistic. In the case of entrusted loans, our evidence suggests they can increase financial stability.

We take advantage of the mandatory disclosure requirement on listed firms when they make entrusted loans and manually collect loan-level data from companies' annual reports and public announcements. We examine the following specific research questions: (1) What kinds of firms tend to make entrusted loans? What motivates lending firms to lend instead of investing in their main businesses? (2) Who are the borrowers? Are entrusted loans likely to allocate capital in certain types of industries or in certain geographic areas? (3) At what prices are entrusted loans provided? How do these prices compare to the official bank loan rate? The difference will shed light on the degree to which the official financing system is distorted. (4) Are entrusted loans 
economic- and information-based? In other words, are they priced commensurate with their risk levels? Further, can the price of a loan (i.e., the interest rate) predict the future loan performance (i.e., the likelihood of default)? (5) Do entrusted loans create or destroy value for the shareholders of the lending firms?

Our investigation reveals that entrusted loans allow privileged firms with access to cheap capital (such as large state-owned enterprises) to provide credit to less-privileged firms (such as small and medium-sized private firms). Lenders of entrusted loans tend to be large, wellcapitalized firms. Their cost of borrowing is similar to or lower than the official bank loan rate whereas they lend out at similar or higher rates. We also find that these loans are more likely to happen when credit is tight. In other parts of the world, it is uncommon that nonfinancial firms engage in making loans since they typically lack a comparative advantage or are barred by regulation from doing so. But China's highly regulated banking system provides an incentive for privileged firms to act as credit intermediaries. Geographically, although many of the loans are provided to firms within the same area, they tend to flow from prosperous provinces/areas to poorer ones and from coastal to inland areas.

Our study also shows that different types of shadow banking activities can be very different in terms of the motives, the types of investments they fund, and their pricing. In the category of entrusted loans, there are two distinctive types — affiliated and nonaffiliated loans. Most affiliated loans are made by a parent firm to a subsidiary; some others are between a customer and a supplier or between business partners in a joint investment. Nonaffiliated loans are between two parties without any prior relationship.

Examining the lender characteristics suggests different motives behind these two types of loans. Lenders of affiliated loans tend to be state-owned enterprises with high profitability, and thus are in good positions to support their affiliated parties. Lenders of nonaffiliated loans, on the other hand, have excess cash but low growth rates and therefore use the loans as an alternative investment channel. 
The two types of loan have striking differences. First, they differ in the industry distribution of their borrowers. Most affiliated loans are within-industry loans. In contrast, close to half of the nonaffiliated loan amount flows into the real estate and construction industry, which regulators try to restrict credit from reaching in order to avoid exacerbating risks in the sector.

Second, the interest rates of nonaffiliated loans reflect the market rate while those of affiliated loans do not. Affiliated loans are essentially pass-through loans. That is, the borrowing firms borrow at the same rate as the lending firms, which is approximately the same as the official bank loan rate. Unlike affiliated lenders, which tend to have high profitability, lenders of nonaffiliated loans have low growth rates and use entrusted loans as an alternative investment channel to their main businesses. Through entrusted loans, they pursue immediate profits by acting as credit intermediaries. The loan rates for nonaffiliated loans, which average $13.9 \%$, are about twice the average official bank loan rate of $6 \%$. The significant difference between these rates suggests that the official financial system is quite distorted: the official loan rate does not properly reflect the true demand and supply of capital.

Consistent with nonaffiliated loans being market-oriented transactions, we find strong evidence that the pricing of nonaffiliated loans depends on both fundamental and informational risks. The adjusted interest rate increases if the borrower is in a high-risk industry, and decreases if it is a state-owned enterprise (SOE) or when the lender is in the same industry or located in the same city as the borrower (hence the information asymmetry between the parties is lower). Moreover, the likelihood of default and other payback difficulties increases with the loans' interest rates, confirming that the pricing of these loans is risk based. In comparison, the evidence that affiliated loans incorporate risk is weaker.

Finally, we examine whether entrusted loans create or destroy value to lending shareholders by examining the stock price reaction upon the announcement of these loans. Our evidence suggests that nonaffiliated loans are fairly-compensated investments, although investors do react negatively the first time a firm announces such a loan and thus reveals to the market that it lacks 
good investment opportunities in its main business. Announcement returns for affiliated loans are not significantly different from zero, suggesting that they do not destroy value. In other words, although the interest rates are low, the market views these loans as fairly priced investments in the affiliated parties.

This study adds understanding to four important aspects of shadow banking activities. First, we show evidence that China's official banking system is highly distorted in that the bank loan rate is way below the market interest rate, and that entrusted loans involve privileged firms with cheap access to capital channel funds to less privileged firms. Second, we provide evidence on the riskiness of the real investments these loans fund. We document that nonaffiliated loans are riskier than affiliated loans given that a much larger proportion of nonaffiliated loans flow into the real estate industry and they are more likely to have problematic performance ex post. Third, we find entrusted loans, especially nonaffiliated loans, are priced commensurate with fundamental and informational risk, and that they are fairly compensated investments. Our evidence also suggests that because shadow banking can differ markedly in risk and efficiency depending on the transaction type, we must be careful when drawing conclusions about the sector as a whole.

Fourth, our paper provides insights into regulation of shadow banking activities. It is often argued that shadow banking is problematic because it involves avoiding banking regulations in the formal sector and as a result increases systemic risks. Entrusted loans provide an interesting counterexample to this view of shadow banking. Our analysis shows that nonaffiliated entrusted loans are often used to channel funds to risky firms in the real estate and related sectors. If banks were to lend to such firms, systemic risk would indeed be increased. However, entrusted loans have the advantage that they are the assets of the lending firms. These firms are mostly well capitalized and have much higher equity ratios than banks. Their large equity buffers thus act as a firebreak between the risky real estate sector and the banking sector and reduce systemic risk. For these reasons, the entrusted loan market is beneficial for decreasing systemic risk and increasing stability. This points to the desirability of multi-tiered regulation where the regulators 
consider the detailed operation of the shadow banking sector and distinguish between cases where financial stability is decreased and where it is increased.

The authorities issued new rules in 2015 to curb the fast growth of entrusted loans, which resulted in an immediate slow-down of new entrusted loans. But these transactions bounced back shortly after. The amount of entrusted loans decreased by $37 \%$ in 2015 , accounting for $10 \%$ of the total social financing. However, in 2016 , the numbers increased by $37 \%$ to account for $12 \%$ of the total social financing. In the first quarter of 2017 , the annualized growth rate was also high at $16 \% .^{2}$ Often, when regulators increase regulation of one form of shadow banking, other forms increase in response. In 2015, while entrusted loans declined, wealth management products (WMPs) (another form of shadowing banking) surged. Starting from 2016, the authorities intensified efforts to reduce leverage with tighter monetary policy and more stringent regulations on WMPs. Responding to that, there has been a resurgence of entrusted loans. ${ }^{3}$ Shadow banking in China continues to grow since private firms are still restricted from the official banking system and banks still have strong incentives to evade regulatory constraints (e.g., high reserve ratios and strict bank loan quota), hence both demand and supply remain strong.

The literature on China's shadow banking has been growing recently. Wang, Wang, Wang, and Zhou (2016) and Hachem and Song (2016) provide theoretical explanations for the growth of the sector. Chen, He, and Liu (2017) document how China's stimulus package led to its rapid growth. Acharya, Qian, and Yang (2016) study the role of banks in issuing wealth management products, another important form of shadow banking in China. Within this literature on the sector, three papers examine entrusted loans. Each uses a much smaller sample size than our paper, however, and more importantly, each focuses on different research questions. Chen, Ren, and Zha (2016) study the role of banks and find that banks, especially small banks, channel more entrusted

\footnotetext{
2 Date source: People's Bank of China web site.

${ }^{3}$ See Moody's reports $(2016,2017)$ for more discussion of these zigs and zags of the sector's growth.
} 
loans when monetary policy tightens. Yu, Lee and Fok (2015) document that mature and cashrich firms with lower growth opportunities are more likely to make high-interest entrusted loans (which roughly correspond to nonaffiliated loans), consistent with our findings. $\mathrm{He}, \mathrm{Lu}$, and Ongena (2016) look at the announcement returns of entrusted loans, but they do not differentiate between a firm's first and subsequent loans. None of these papers compare lenders' costs of borrowing with their lending rates, or study the asset side and pricing efficiency of entrusted loans.

Our examination of affiliated loans is related to a number of existing studies of intra-businessgroup loans. Gopalan, Nanda, and Seru (2007) and Buchuk, Larrain, Munoz, and Urzua (2014) investigate intra-group loans in India and Chile, respectively, and document benefits of these loans such as reducing the likelihood of bankruptcy, alleviating financial constraints, and increasing investments in the borrowing firms. ${ }^{4}$ Our work complements both studies by providing evidence that pricing of affiliated loans is economic based and that the loans on average are fair investments. Jiang, Lee, and Yue (2010) document that controlling shareholders of Chinese-listed firms used intra-group loans for tunneling during the period 1996-2006 and that the practice was ended by 2006 after a series of regulatory rules and directives. ${ }^{5}$ Using post-2004 Chinese data, Chen, Jiang, Ljungqvist, $\mathrm{Lu}$, and Zhou (2015) present evidence that state-owned intra-group capital flows likely go to firms with low investment opportunities, whereas private groups do the opposite. Such support activities may not be inefficient after considering factors such as bankruptcy costs (Gopalan, Nanda, and Seru, 2007). Our wealth-effect tests suggest that the market does not believe affiliated loans destroy value for lenders. ${ }^{6,7}$ To the best of our knowledge, our paper is the first to systematically study the pricing and wealth effects of affiliated loans.

\footnotetext{
${ }^{4}$ For a discussion of the general literature on business groups and internal capital markets, see Buchuck, Larrain, Munoz, and Urzua (2014).

${ }^{5}$ La Porta, Lopez-de-Silanes, and Zamapripa (2003) also document that related lending by banks in Mexico in 1990s is a form of looting.

${ }^{6}$ Consistent with Chen, Jiang, Ljungqvist, Lu, and Zhou (2015), we find that the announcement returns of affiliated loans tend to be higher for loans made by non-SOE lenders than those by SOE lenders. Nonetheless, the differences are not statistically significant.

${ }^{7}$ Our sample is different from that of Chen, Jiang, Ljungqvist, Lu, and Zhou (2015). While they examine capital flows among firms with the same ultimate controlling shareholder, our affiliated loans are mostly between listed
} 


\section{Sample and Data}

According to the regulations of the China Securities Regulatory Commission (CSRC), listed companies are required to disclose, in audited annual reports, the entrusted loans they make. Corporations can receive warnings or face lawsuits from CSRS for failing to comply with the disclosure requirements. The data quality on entrusted loans should therefore be as good as other accounting variables from annual reports, which are widely used in studies about Chinese firms.

We manually collect our sample and data by searching for the keyword "entrusted loan" in all public nonfinancial firms' annual reports during the period 2004-2013. We use a keyword search because the disclosure format lacks uniformity, especially before $2011{ }^{8}$ We then read the context around the "entrusted loan" hits to decide whether the information is relevant. An annual report discloses all loans outstanding by the year end. To ensure each observation corresponds to a newly originated loan, we compare the list of loans with those in the firm's previous annual report to identify new loans. For each new loan, we identify the lender and the borrower and record loan characteristics such as the loan amount, the interest rate, the maturity, and whether the two parties are affiliated.

We supplement the annual-report data with entrusted loan announcements. Not all firms make interim announcements about their entrusted loans. The regulatory requirement on such announcements is vague. That is, firms need to make announcements about "material" investments and events, but there is no technical definition of what is considered material. When announcements are available, we use them to cross-check data from annual reports and to fill in

parent firms and subsidiaries; the motives for support can be very different. Their data do not reveal the repayment of the loans and trade credit; our data clearly show that the majority of the loans $(91.4 \%)$ are fully repaid on time.

${ }^{8}$ In earlier years of the sample period, information about entrusted loans can often be found in footnotes to the balance sheet or in other sections, such as "Major Events." In 2011, CRSC specified that the information should be disclosed in the section "The Board's Report-Investments Analysis." After 2011, all the loans are listed in the specified section, but some relevant information (e.g., loan characteristics) is sometimes discussed in other parts of the annual report. 
any missing information. Knowing the announcement dates also allows us to examine stock price reactions to these loans.

In Appendix A, we use a few detailed examples to show how we identify new loans and locate the information we need. Appendix A also illustrates how we use annual reports and interim announcements to cross-check information.

We obtain additional information about the lenders from Wind Database, which provides accounting and return data for listed firms. In our sample, the majority of borrowers (99\%) are private firms, so we have limited information about them. We collect data on a borrower's industry and headquarters location and on whether it is an SOE based on information provided by the lender or by our own manual search.

Our sample includes 2,995 entrusted loans made by 498 unique firms that correspond to 1,107 firm-years during the period 2004-2013. In this period, the entire public market of China had 2,467 unique nonfinancial firms that corresponded to 18,003 firm-years.

Table 1 reports by year the number of listed firms that make new entrusted loans, the number of loans, and the total loan amount. We observe a fast-growing trend of entrusted loans. The number of firms making entrusted loans increases from 55 in 2004 to 220 in 2013 . The total amount of the loans takes more than a tenfold leap, from 12.6 billion RMB in 2004 to 219.2 billion RMB in 2013. 


\section{Who Makes Entrusted Loans and When?}

We investigate what types of firms make entrusted loans. What motivates lending firms to lend instead of investing in their main businesses? What differentiates firms that make loans from those that do not? In addition, we compare lenders of affiliated loans with those of nonaffiliated loans.

Table 2 reports the descriptive statistics of lender characteristics. The first two columns show the mean values of variables for firm-years with and without entrusted loans. Columns (3) and (4) report characteristics of lenders of nonaffiliated and affiliated loans, respectively. Compared to nonlenders, both types of lenders are much larger in asset-value terms (10.6 billion RMB for nonaffiliated lenders and 21.0 billion RMB for affiliated lenders versus 5.8 billion RMB for nonlenders). Both types of lenders are also well-capitalized firms, although affiliated lenders' average debt ratio is slightly higher than nonlenders $(16.7 \%$ for nonaffiliated lenders, $23.5 \%$ for affiliated lenders, and $20.7 \%$ for nonlenders).

The two types of lenders differ in other aspects. Again benchmarked against nonlenders, affiliated lenders have higher profitability measured by return on assets (ROA; 7.6\% versus 6.9\%), higher debt ratios (23.5\% versus $20.7 \%$ ), more recently issued debt (change of debt ratio $8.7 \%$ versus $4 \%$ ) and less cash holding as a percentage of assets (17.2\% versus $19.4 \%)$; affiliated lenders are also more likely to be SOEs $(79.9 \%$ versus $54.6 \%)$ and in the real-estate business $(11.8 \%$ versus $8.4 \%$ ). These characteristics suggest that larger, SOE firms with higher profitability are more likely to provide affiliated loans, and that these firms likely depend on external financing rather than internal cash for the lending. ${ }^{9}$

\footnotetext{
${ }^{9}$ This is suggested by affiliated lenders' low cash holdings and increased debt ratios before loan issuance. Although we can't usually pin down the sources of funds lenders use for entrusted loans, we observe anecdotal evidence that firms borrow externally, e.g., by issuing bonds, to fund entrusted loans. For example, Guangxi Guiguan Electric Power Co. issued 2 billion RMB of bonds in January 2013 with a maturity of 3 years and a coupon rate of 5.6\%. Within 50 days of the bond issuance, the company spent 0.94 billion RMB on 5 entrusted loans to 5 majority- or wholly-owned subsidiaries, each with an interest rate of $5.535 \%$ and a maturity of 3 years. In another case, Foshan NationStar Optoelectronics Co. issued 500 million RMB of bonds in May 2012, with a maturity of 5 years and a coupon rate of $6.8 \%$. Two months later, the company lent 300 million RMB to a majority-owned subsidiary at a rate of $7 \%$, maturing in 3.5 years. The company stated explicitly in the loan announcement that they used the proceeds of the bond issuance to make the entrusted loans.
} 
Unlike affiliated lenders, firms making nonaffiliated loans do not differ significantly from nonlenders in ROA, new debt, and the likelihood of being an SOE or a real-estate company. In fact, they actually have a lower sales growth rate $(18.0 \%$ versus $23.6 \%)$, lower debt ratios $(16.7 \%$ versus 20.7\%), and higher cash holdings (21.4\% versus $19.4 \%)$ than nonlenders. These characteristics suggest that large firms with excess cash but a low growth rate tend to make nonaffiliated loans.

Borrower size is not typically disclosed in lenders' annual reports. In unreported results, we are able to find asset values of borrowers in 509 loan announcements. For those 509 transactions, the median borrower asset value is 0.4 billion RMB (versus 4 billion RMB for lenders). According to the size classification criteria by China Bureau of Statistics, the asset value is associated with a medium-size company. As noted before, $99 \%$ of the borrowers in our data are private firms. So a typical borrower is a private medium-size company.

We then run multivariate regressions to explore the determinants of the loan decisions. Table 3 reports two types of regressions. In the first three columns, we report logit regressions using Loan dummy (an indicator that there is an entrusted loan for the firm-year) as the dependent variable. For each regression, we include both firm-years with and without loans. The loan sample includes firm-years with both types of loan, nonaffiliated loans only, and affiliated loans only in Columns (1)-(3), respectively. In the last three columns, we report Tobit regressions using the ratio of the amount of loan to total assets as the dependent variable and zero as the lower limit. In Table 3 Panel A, industry and year fixed effects are included. In Panel B, we include a measure for the condition of the economy, namely the Shanghai interbank offered rate (Shibor), which measures the overall availability of liquidity and credit in the economy. We obtain daily data on Shibor from the China Center for Economic Research (CCER) Database, and use the yearly average in the regression. The yearly averages for our sample periods range from $1.1 \%$ in 2009 and $3.4 \%$ in 2013 . When including the yearly measure, we drop year fixed effects in panel B. In both panels, standard errors are double-clustered by firm and year in each regression. 
We first look at the logit regression results in Table 3 Panel A. The coefficient on $\ln$ (assets) is significant and positive in both Columns (2) and (3), suggesting that larger firms are more likely to make both types of loan. Other than this common determinant, the decision to make affiliated or nonaffiliated loans is influenced by several different factors. The likelihood of affiliated loans increases if the firm has higher profitability (measured by ROA), if the firm has raised more debt recently and if the firm is an SOE. The likelihood of nonaffiliated loans, on the other hand, decreases with the firm's sales growth rate and its debt ratio and increases with firm age.

The Tobit regression results are similar. In addition, Column (5) shows that cash-rich firms tend to make more nonaffiliated firms. Yu, Lee and Fok (2015) document that older, more cashrich firms and firms with lower Tobin's Q are more likely to make high-interest-rate entrusted loans. Given that high-interest-rate entrusted loans roughly correspond to nonaffiliated loans (see section 4 for rate comparison), our findings on cash holding and firm age are consistent with theirs. ${ }^{10}$

Table 3 Panel B reports the regression results when including Shibor. We find positive coefficients on Shibor in all six regressions. This further confirms that entrusted loans increase when credit is tight in the economy. In terms of the economic significance, when Shibor increases from its 25 th percentile to 75 th percentile, the probability of making a nonaffiliated loan increases from $1.4 \%$ to $1.8 \%$, and the probability of making an affiliated loan increases from $4.0 \%$ to $4.7 \%$, assuming all other explanatory variables are at their means.

We also examine whether the results are different for different periods of time. We divide the sample into before and after (including) 2010 and re-estimate Table 3 regressions (results are reported in the internet appendix). Overall, the main results are similar in both subsamples. One difference is that Shibor is significant only in the second period. Further investigation reveals that

\footnotetext{
${ }^{10}$ We do not find the likelihood of nonaffiliated loans depends on a firm's Tobin's Q. We do find that firms with a higher growth rate are less likely to make nonaffiliated loans. The coefficient on Tobin's Q remains not statistically significant if we exclude sales growth rate.
} 
Shibor is a less suitable measure for the credit market condition in earlier years and has become a valid benchmark rate in more recent years. ${ }^{11}$

In summary, both types of loan increase with the lender's size and when credit is tight in the economy. These findings indicate that entrusted loans are market reactions to credit shortage. They allow privileged firms (large listed firms) with cheap access to capital to channel funds to less privileged firms (small and medium-sized private firms). However, there are important differences between the two types of lenders. Lenders of affiliated loans tend to be SOEs, have high profitability, and have raised new debt recently. These characteristics suggest that they are in good positions to support their affiliated parties and that they do not mind raising new capital to finance the loans. On the other hand, lenders of nonaffiliated loans have excess cash but low growth rates and therefore use the loans as a new channel to generate profits and growth.

\subsection{Entrusted lending firms vs. banks}

Lenders of entrusted loans, being non-financial firms, do not have comparative advantages to intermediate credit. They become a phenomenon in China due to the segmented credit markets and the motive of regulatory arbitrage. They also do not have diversified loan portfolios. Nonetheless, entrusted loans pose limited risk to the lenders in our sample for several reasons. First, these lenders are large listed firms and have privileged access to debt and equity capital. ${ }^{12}$ Second, they make a limited number of loans and the capital involved consists of small percentages of their capital. The average lender makes 6.0 loans during the whole sample period, 2.7 loans a year when it does make any loan. For those firm-years with loans, the average ratio of

\footnotetext{
${ }^{11}$ A 2009 China Daily article states, "But aside from a few signs of interest spurred mostly by central bank prodding, SHIBOR has largely been collecting dust. Money market traders long shunned it, complaining that contributors of the quotes - mostly cash-rich Chinese banks overwhelmingly on the offering side of transactions - tended to manipulate fixings to keep rates high and maximize their profits." The same article, also points out that a number of changes in 2009 including tightening monetary policy and increased use of floating rate notes and interest rate swaps lifted the prospects of Shibor as a benchmark rate. Over time, as China's interbank borrowing market continues to grow (from 1.4 trillion in 2004 to 35.5 trillion in 2013), Shibor has become a valid indicator for the credit market.

${ }^{12}$ See Section 4.1 and Table 5 for more detailed discussion.
} 
loan amount to the lending firm's assets is $5.1 \%$, and the mean loan amount relative to the lenders' mean operating cash flow is $37 \%$.

Third, the lenders are well capitalized firms with high liquidity ratios. By comparing lenders in our sample and listed banks (results are reported in the internet appendix), we observe that lenders have lower leverage ratios and higher liquidity ratios than banks. For example, the median debt-to-assets and total-liabilities-to-assets ratios are $20 \%$ and $51 \%$ for entrusted lenders, whereas both ratios are more than $90 \%$ for banks. The median current ratios are $132 \%$ for lenders, whereas the ratio is $77 \%$ for listed banks.

For these reasons, entrusted loans are unlikely to pose high risk or liquidity problems to lenders. We verify this by examining the likelihood of a lender being sued due to debt default in the three years following making an entrusted loan. We obtain data from CCER (China Center for Economic Research) database of "Major Events - Lawsuits and Arbitrations" and search for lawsuits due to debt default. We find that the likelihood of default and being sued is lower for entrusted loan lenders ( $1.1 \%$ for affiliated lenders, $1.0 \%$ for nonaffiliated lenders) than other listed firms $(2.5 \%)$.

In addition, although lenders do not have the general expertise of monitoring borrowing firms, that they tend to lend to firms they are familiar with - those in the same industry and/or in geographical proximity (details in section 4). Such measures should largely reduce information asymmetry problems and makes monitoring easier. We also verify that the loss ratio of affiliated and nonaffiliated loans are small: $0.57 \%$ for nonaffiliated loans, and $0.29 \%$ for affiliated loans compared to $0.61 \%$ for listed banks (details in section 5).

Altogether, the evidence suggests that entrusted loans pose limited risk to lending firms. By moving the credit from the balance sheet of banks to these well-capitalized firms, entrusted loans can decrease systemic risk and increase stability. 


\section{Which Firms Are Borrowing, and at What Price?}

We now examine the entrusted loans at the transaction level, as opposed to the firm-year level. Out of the 2,995 loans in our sample, we can identify the borrower and loan characteristics in 2,960 cases. Affiliated loans constitute $80 \%$ of the sample in terms of the number of loans and $93 \%$ in terms of the loan amount.

\subsection{Interest rate: Affiliated loans versus nonaffiliated loans}

The most striking difference between affiliated and nonaffiliated loans is in the interest rate: affiliated loans command about half the rate that nonaffiliated loans do. Table 4 reports the average interest rate for each type of loan by industry. The average interest rate is $6.4 \%$ for affiliated loans versus $13.9 \%$ for nonaffiliated loans. We calculate the adjusted interest rate as the difference between the loan rate and the official bank loan rate specified by the central bank categorized by maturity. The official rate ranges from $4.9 \%$ to $7.8 \%$ in our sample period and has a mean of $6.1 \%$. The average adjusted rates for affiliated and nonaffiliated loans are $0.3 \%$ and $7.9 \%$, respectively.

The near zero adjusted interest rate suggests that affiliated loans charge about the same rate as official bank loans. In China, the cost of borrowing for most firms - a small group of privileged firms (i.e., the large SOE firms) excluded — is much higher than the official bank loan rate (Song, Storesletten, and Zilibotti 2011). The low interest rate indicates that affiliated loans are used to support a subsidiary or to build a long-term relationship with a supplier or a customer. For example, in 2006, SAIC Motor, the largest listed auto company in the China A-share stock market, provided a five-year low-interest loan of 94 million RMB to Ningbo Huaxiang Electronic, a major supplier of automotive components. SAIC Motor stated in its annual report that the purpose of the loan was to ensure the supplier will provide quality components on schedule. Whether these loans with below-market rates are inefficient subsidies or long-term investments is an open question. The lenders might gain long-term benefits, such as returns from equity investment of the 
subsidiaries, stable and high-quality supplies from suppliers, or stable demand from customers.

The rates of nonaffiliated loans, on the other hand, reflect the market cost of borrowing for small and medium-sized private firms, typically double the official bank loan rate. This reflects how distorted the official banking system is. It is the regulatory restrictions on bank loan access that give nonfinancial firms incentives to act as credit intermediaries, which they have no comparative advantages to do in a market-oriented financial system.

It is also clear from Table 4 that the high interest rates of nonaffiliated loans are broadly based, not concentrated in a few industries. The average rates for various industries range from $6.9 \%$ to $16.1 \%$, and are higher than $10 \%$ for 19 out of 23 industries.

We also try to gauge the lenders' cost of borrowing for comparison. We use the yields of newly issued bonds as a measure for firms' cost of borrowing. ${ }^{13}$ The Chinese database WIND provides comprehensive coverage for bond issuances in China. We obtain 2,052 bond issuances corresponding to 1,425 firm-years during our sample period (excluding nonfinancial firms). Within this sample, 247 firm-years made entrusted loans (244 have nonmissing cost of bond information). Notice that the lenders of entrusted loans are much more likely to issue bonds than firms in general (22\% versus $7 \%)$, suggesting they either have better access to the bond market or issue bonds to make entrusted loans, or both.

Table 5 reports the summary statistics of bond costs for lenders of entrusted loans. Panel A reports the adjusted cost of bonds, benchmarked against the official bank loan rate. If a firm has multiple bonds in a year, we use the weighted average cost of the bonds. We divide the sample into SOE versus non-SOE firms. Panel A shows that lenders' bond cost is lower than the bank loan rate, which is not surprising. Moreover, SOE lenders of entrusted loans enjoy even lower rates than non-SOE lenders. Panel B compares lenders' cost of borrowing to the rate they charge on the entrusted loans they make. Here we use each entrusted loan as an observation, and we

\footnotetext{
${ }^{13}$ A caveat of the analysis is that the corporate bond market in China is not nearly as developed as that in the United States, and the majority of listed firms do not issue public bonds. Their main borrowing source is bank loans.
} 
calculate the difference between the adjusted interest rate of the entrusted loan and the firm's adjusted cost of bonds. The panel shows that both SOE and non-SOE lenders enjoy rate profitsthat is, the rate they charge is higher than their cost of bonds. They charge about a 1.2-1.8 percentage-point premium when making affiliated loans, and a 9-10 percentage-point premium when making nonaffiliated loans. We do not find the rate premiums differ significantly between SOE and non-SOE lenders.

Table 5 shows that lenders of entrusted loans enjoy low borrowing costs, and they use their advantageous positions either to support their affiliates or to make profits.

In summary, borrowers of affiliated loans pay similar rates as the lenders do when borrowing - the official bank loan rate or lower. On the other hand, the nonaffiliated lenders act as credit intermediaries and charge a market rate, which is much higher than the official bank loan rate. The substantial differences in these rates indicate that the official banking system is quite distorted. The artificially low bank loan rates and the restricted access to the banking system for the more productive private sector have led to the exponential growth of shadow banking.

\subsection{Industry distribution of lenders and borrowers}

The second striking difference between affiliated and nonaffiliated loans is the industry distribution of the borrowers. Questions abound as to whether shadow banking helps circumvent the regulatory restrictions on the red-hot real estate and construction industry and mainly provides capital to that industry. Our study shows that the two types of loan are very different in this regard.

Most of the affiliated loans $(80.6 \%)$ are within-industry loans. Table 6 Panel A presents the amount, in RMB, of entrusted loans by lender and borrower industries. The real estate and construction industry receives $12.2 \%$ of the total affiliated loan amounts ( 77.8 out of 638.5 billion RMB). Based on a recent IMF report on China (2014), real estate and construction "directly accounted for 15 percent of 2012 GDP, a quarter of fixed-asset investment, 14 percent of total urban employment, and around 20 percent of bank loans" (page 22). Benchmarked against these 
numbers, the amount of affiliated loans going to the real-estate and construction industry is not high. In particular, the percentage of affiliated loans to the industry is lower than that of bank loans. Moreover, the rest of the loans have a reasonably diverse distribution among over twenty broadly defined industries.

A much larger portion of nonaffiliated loans flows into real estate and construction. The industry's borrowing accounts for $46.1 \%$ of the total amount of the nonaffiliated loans. Since 2011, the China Banking Regulatory Commission (CBRC) has tried to restrict bank loans to the real estate and construction industries since they are perceived to be overheated. Bank lending to the industry shrank by 38\% from 2.02 trillion RMB in 2010 to 1.26 trillion in 2011 and 1.35 trillion in $2012 .{ }^{14}$ In contrast, in our sample the total borrowing of nonaffiliated loans by the industry jumped to 16.2 billion RMB during the period 2011-2013, compared to a total of 5.7 billion RMB during 2004-2010. This suggests that nonaffiliated loans do help to circumvent regulatory restrictions and channel more capital into the real estate and construction industry. Given that the industry's high return volatility and the fact that it is widely viewed as overheated, concentrating on this industry makes nonaffiliated loans riskier than affiliated loans. The overall risk of entrusted loans will increase with the fraction of nonaffilitated loans.

Our study focuses on entrusted loans made by listed firms. It is worth noting that in recent years (starting in 2009, the year of the 4 trillion RMB stimulus package), another type of lenderprivate equity funds - has gained an increasing market share of entrusted loans. Although we do not have direct data on this group of loans, our understanding based on interviews with practitioners is that these loans are driven by the pursuit of immediate profits. Therefore, they have characteristics associated with nonaffiliated loans-most noticeably, they command high interest rates and are more likely to flow into restricted industries such as real estate and construction. In January 2015, the CBRC instituted new rules on entrusted loans. One important

\footnotetext{
${ }^{14}$ Data source: the website of the People's Bank of China.
} 
change is that debt-financed funds are prohibited from making entrusted loans, which aims to exclude these private equity players from this market.

\subsection{Geographic distribution of lenders and borrowers}

Table 6 Panel B presents the geographic distribution of lenders and borrowers. Specifically, it shows the RMB amounts of lending and borrowing from each province or area, for both affiliated and nonaffiliated loans. ${ }^{15}$ Figure 1 offers a visual presentation of the geographic distribution on the China map.

Affiliated loans are largely concentrated in the two biggest cities directly controlled by the central government—Beijing and Shanghai. Lenders from Beijing make up about $54.7 \%$ of the total affiliated loans and those from Shanghai make up 12.4\%. They are followed by Shandong, Zhejiang, and Guangdong provinces. One important reason for the concentration is that $83.3 \%$ of affiliated loans are made by SOEs; in general, SOEs - especially large SOEs - are largely headquartered in Beijing or Shanghai. ${ }^{16}$ Another driver for the loans' geographic distribution is the economic prosperity of different provinces and areas. According to the WIND database, the five provinces/areas that lend most are ranked as 1st (Shanghai), 2nd (Beijing), 3rd (Zhejiang), 6th (Guangdong) and 9th (Shandong) in terms of per capita disposable income in $2013 .{ }^{17}$ Except for Beijing, they are all located in coastal areas.

The five largest borrowing provinces/areas are Beijing, Shanghai, Jiangsu, Inner Mongolia, and Guangdong. It is not surprising that three of these are also among the provinces/areas that lend the most; $51.6 \%$ of affiliated loans are between parties from the same province/area and $35.7 \%$ of affiliated loans are within the same city.

\footnotetext{
${ }^{15}$ In addition to 23 provinces, China has four municipalities (Beijing, Shanghai, Tianjin, and Chongqing), five autonomous regions (Guangxi, Inner Mongolia, Tibet, Ningixa, and Xinjiang) and two special administrative regions (Hong Kong and Macau).

${ }^{16}$ By the end of 2013, 4.4\% and 4.3\% of all listed SOE firms were headquartered in Beijing and Shanghai, respectively (top two among all provinces and areas), and these firms controlled $24.5 \%$ and $7.2 \%$ of all listed SOE firms' market value of assets (again top two among all provinces and areas).

${ }^{17}$ Ranks exclude data from Hong Kong, Macau and Taiwan.
} 
Inner Mongolia stands out as the area with the highest net borrowing amount (borrowing minus lending amount): it lends zero and borrows 34.4 billion RMB. The next four provinces in terms of net borrowing are Jiangsu, Shaanxi, Sichuan, and Liaoning. These provinces' per capita disposable incomes in 2013 are ranked as Jiangsu (5th out of 31), Liaoning (8th), Inner Mongolia (10th), Shaanxi (22nd), and Sichuan (23rd). Inner Mongolia, Shaanxi, and Sichuan are located inland. These data suggest that entrusted loans spill over from prosperous provinces/areas to poorer ones and from coastal to inland areas (see also Figure 1).

Nonaffiliated loan activities are most active in Zhejiang province, which is also the province with the highest per capita disposal income after Shanghai and Beijing. Private enterprises are very active in Zhejiang. It is second only to Guangdong in terms of market value of assets of nonSOE listed firms. The lending amount from Zhejiang alone is $41.4 \%$ of total nonaffiliated loans, and its borrowing amount is $30.6 \%$ of total loans.

Nonaffiliated loans are even more likely than affiliated loans to occur between parties from the same province/area (73.9\%) or even from the same city $(51.3 \%)$. Following Zhejiang, the other provinces/areas active in nonaffiliated loan activities are, in order of lending plus borrowing, Jiangsu, Shanghai, Beijing, and Guangdong. These are all prosperous provinces/areas.

In terms of net lending (i.e., lending minus borrowing amount), Zhejiang ( $10.8 \%$ of total amount) and Guangdong (3.0\%) lend the most. The net borrowing amounts of Shanghai (5.1\%), Guangxi (3.3\%), Guizhou (1.3\%) and Jiangsu (1.0\%) exceed 1\% of the total amount of nonaffiliated loans. Guangxi and Guizhou are poor provinces - their per capita disposable incomes in 2013 are ranked 25th and 29th, respectively, out of 32 areas. So nonaffiliated loans mostly happen in prosperous areas with already active commercial and economic activities, but again there is some evidence that capital flows from prosperous provinces/areas to poorer ones, and from coastal to inland areas. 


\subsection{Other loan characteristics}

Table 7 presents summary statistics for other loan characteristics, as well as borrower and lender characteristics. Compared to nonaffiliated loans, affiliated loans tend to be larger (with a mean of 269 million RMB versus 81 million RMB), have longer maturity (18 months versus 12 months), and to be less likely to need collateral and guarantee (11\% versus $74 \%)$. In addition, only affiliated loans may be used to retire earlier debt (3\% versus $0 \%)$. Affiliated loans are also more likely to be used for specified projects ( $6 \%$ versus $3 \%$ ). These findings are consistent with prior studies that find borrowers who have relationships with lenders receive favorable terms such as greater credit availability and lower collateral requirements (Petersen and Rajan, 1994, Berger and Udell, 1995).

The percentage of SOE borrowers for nonaffiliated loans is much lower than that for affiliated loans (20\% versus $78 \%)$. This suggests that it is the least privileged firms - the small non-SOE firms - that are taking entrusted loans from nonaffiliated parties at market interest rates that are much higher than the official bank loan rates.

Table 7 shows that lenders tend to lend to firms they are familiar with, i.e., those in the same industry or in geographical proximity. A large share of affiliated loans is made within the same industry ( $81 \%$ vs. $10 \%$ for nonaffiliated loans). Nonaffiliated lenders, on the other hand, are more likely to lend to firms in the same city (51\%, versus $36 \%$ for affiliated loans).

\section{The Pricing of the Loans}

\subsection{Do loan rates depend on risk?}

In this section, we investigate what determines the interest rate of the entrusted loans. Allen, Qian, and Xie (2018) argue that constructive (information-based) informal financing plays an important role in China's financial market. We investigate whether the pricing depends on the borrower's fundamental and informational risks. 
Since most (99\%) of the borrowers are private firms, the available information about them is limited. We obtain each borrower's name from the lender's disclosure statement and collect information about its industry, location, and whether it is an SOE either from the lenders' disclosure or from a manual search.

To measure a borrower's business risk, we consider its industry risk and whether the firm is an SOE. We use three variables to measure industry risk: (1) borrower industry return volatility high, a dummy equal to one if the industry return volatility is above median during the year before the loan is made, where industry return volatility is computed as the median of the standard deviations of daily returns for firms in the borrower industry; (2) borrower industry sales growth dispersion high, a dummy equal to one if the industry sales growth dispersion is above median during the year before the loan is made, where the dispersion is computed as the standard deviation of sales growth of firms in the borrower industry; (3) real estate borrower, a dummy variable equal to one if the firm is in the real estate and construction industry. Firms in the real estate and construction industry are often considered to be of high risk, as many worry about the bubble in the housing market (e.g., Wu, Gyourko, and Deng, 2012). In addition, despite the general increase in housing prices during our sample period, firm performance in the industry varies widely. For example, its average (across years) industry sales growth dispersion is $106 \%$, the highest among all industries, and its average (across years) industry median return volatility is $3.09 \%$, sixth among all the industries. The correlation of real estate borrower and borrower industry sales growth dispersion is 0.70 , and the correlation of real estate borrower and borrower industry return volatility is 0.17 . At the firm level, a firm tends to have lower debt risk if it is an SOE since SOEs typically have better access to official financing and therefore have higher abilities to meet their debt obligations.

We use two variables to measure the extent of information asymmetry between the borrower and the lender: a dummy variable indicating whether they are in the same city and a dummy indicating whether they are from the same industry. Prior research on bank loans document that 
banks located closer to borrowing firms incur lower information production and monitoring costs (e.g. Degryse and Ongena, 2005; Mian, 2006). It is also reasonable to think that lenders understand borrowers from the same industry better.

Table 8 presents univariate analysis of the impact of these risk measures on interest rates. Specifically, we compare the mean adjusted interest rates between subsamples of loans that differ by risk measures.

Consistent with the informational risk hypothesis, the results show that for nonaffiliated loans, borrowers located in the same city as lenders pay lower interest rates (the mean adjusted interest rate is $7.2 \%$ versus $8.6 \%$, and the difference is statistically significant at the $1 \%$ level). For affiliated loans, the rate is also lower for same-city loans, but the difference is much smaller $(0.2 \%$ versus $0.4 \%$, and the difference is significant at the $10 \%$ level). In addition, we recall that the percentage of same-city loans is higher for nonaffiliated loans. This is consistent with the notion that firms are more willing to lend to a nonaffiliated firm if it is in the same city and therefore presents lower informational risk. In comparison, geographic distance is not as important a factor for affiliated loans. It is plausible that these lenders have good information about affiliated parties regardless of whether they are from the same city. It may also be that affiliated lenders are less sensitive to risk.

Also consistent with the informational risk hypothesis is our finding that the interest rate is lower if both parties are from the same industry. In our sample, $81 \%$ of affiliated loans and $10 \%$ of nonaffiliated loans occur between two firms in the same industry. The high proportion of within-industry loans for affiliated loans is determined by the nature of the ownership or business affiliations. For nonaffiliated loans, within-industry loans command lower adjusted interest rates $(6.0 \%$ versus $8.1 \%)$. For affiliated loans, within-industry loans also have lower adjusted interest rates $(0.1 \%$ versus $1.3 \%)$. The same-industry factor seems to have a larger impact on the interest rate than the same-city factor has for affiliated loans, but the impact is again smaller than that for the nonaffiliated loans. 
Table 8 also reports the mean adjusted interest rate conditional on whether the borrower is an SOE. In China, SOEs usually enjoy better access to bank loans as major banks are also stateowned. The majority of the lenders of both affiliated loans and nonaffiliated loans are SOEs ( $83 \%$ and $64 \%$, respectively), but for nonaffiliated loans, only $20 \%$ of borrowers are SOEs (versus $66 \%$ for affiliated loans), suggesting borrowers of nonaffiliated loans are underprivileged firms that have restricted access to official financing. We observe that non-SOE borrowers pay significantly higher adjusted interest rates than SOE borrowers $(8.8 \%$ versus $4.2 \%$ for nonaffiliated loans, and $0.7 \%$ versus $0.2 \%$ for affiliated loans). This reflects non-SOE firms' higher firm risk (they are often smaller firms) as well as their lower bargaining power due to their restricted access to official financing.

Table 8 shows that risky borrowers pay higher interest rates. Specifically, real-estate borrowers pay higher adjusted interest rates than non-real-estate borrowers $(9.5 \%$ versus $6.6 \%$ for nonaffiliated loans, and $2.8 \%$ versus $-0.2 \%$ for affiliated loans); borrowers with above-median industry return volatility pay higher rates than those with below-median volatility $(9.0 \%$ versus $6.7 \%$ for nonaffiliated loans, and $0.5 \%$ versus $0.1 \%$ for affiliated loans); and borrowers with above-median industry sales growth dispersion pay higher rates than those with below-median dispersion ( $8.5 \%$ versus $6.8 \%$ for nonaffiliated loans, and $0.8 \%$ versus $-0.2 \%$ for affiliated loans). All the differences are statistically significant.

Next we estimate multivariate regressions to see whether borrower risk still explains the variation in interest rate after controlling for other factors. The dependent variable is the adjusted interest rate. For control variables, we include the loan- and lender-characteristic variables listed in Table 7. For affiliated loans we also include two additional variables: ownership, which measures the lender's equity ownership in the borrower, and trade relationship, which is a dummy variable equal to one if the borrower is a customer, a supplier, or a business partner of the lender in joint investments. Industry and year fixed-effects are included, and standard errors are double clustered by firm and year in each regression. 
Table 9 reports the regression results for the samples of nonaffiliated loans (Panel A) and affiliated loans (Panel B). The results suggest that the interest rate increases with a borrower's risk. For both types of loan, the coefficients on all three borrower-industry risk measuresborrower industry return volatility high, borrower industry sales growth dispersion high, and real estate borrower - are positive and statistically significant at the $1 \%$ level. If the borrower is in a high-risk industry based on return volatility, the adjusted rate increases by 1.0 percentage point for nonaffiliated loans and 0.6 percentage points for affiliated loans. If the borrower is in a highrisk industry based on growth dispersion, the adjusted rate increases by 1.4 percentage points for nonaffiliated loans and 0.4 percentage points for affiliated loans. If the borrower is in the realestate industry, the adjusted rate is higher by 2.5 percentage points for nonaffiliated loans and 2.7 percentage points for affiliated loans. The coefficient on SOE borrower is significantly negative for nonaffiliated loans. If the borrower is an SOE, the interest rate is on average lower by 3.1 percentage points. The coefficient on SOE borrower, however, is nonsignificant for affiliated loans, possibly because affiliated parties receive favorable rates regardless of their SOE status.

Informational risk also has positive impact on the interest rate of both types of loan, and the effects are stronger for nonaffiliated loans. If located in the same city as the lender, a borrower pays on average a lower interest rate $(0.9$ to 1.6 percentage points lower for nonaffiliated borrowers and 0.3 to 0.4 percentage point lower for affiliated borrowers). A borrower in the same industry as the lender is also charged a lower rate (1.6 to 2.1 percentage points lower for nonaffiliated borrowers and 0.2 to 0.8 percentage point lower for affiliated borrowers).

For both types of loan, the adjusted interest rate is negatively related to the loan maturity and positively related to the use of collateral or guarantees. This suggests that these contract terms are used simultaneously as complements to each other to control the investment risk. That is, in addition to charging higher rates, lenders will limit their risk exposure by forcing riskier borrowers to take shorter-term loans and to secure the debt with collateral or a guarantee. This observation is consistent with existing studies on bank loans (e.g. Flannery, 1986; Burger and Udell, 1990; 
Dennis, Nandy, and Sharpe, 2000). The effects of maturity and use of collateral/guarantee are stronger for nonaffiliated loans than for affiliated loans.

In summary, Table 9 shows that the pricing of both nonaffiliated loans and affiliated loans take into account the borrowers' fundamental risk and information risk. Nonetheless, the rates of nonaffiliated loans are much more sensitive to informational risk (whether the borrower is in the same city or same industry as the lender) than those of affiliated loans. As there is more information asymmetry between nonaffiliated lenders and borrowers, being in the same city or industry helps to mitigate the information problem. An SOE borrower also provides stronger assurance to nonaffiliated lenders.

\subsection{Loan rate and loan performance}

As an alternative way to test whether the pricing of entrusted loans efficiently incorporates risk, we examine whether the interest rate can predict the future performance of loans. That is, if riskier loans command higher rates, then higher rates should be associated with higher likelihoods of default or other payback difficulties.

We manually collect information about the outcome of entrusted loans from firms' annual reports. The lending firm must disclose when a loan is delinquent, overdue, or extended. By interviewing practitioners, we learned that loan extensions are usually due to borrowers having difficulty paying their loan back on time. We include 2,243 loans in this analysis that were originally due by the end of 2013 (1,782 affiliated loans and 461 nonaffiliated loans).

Panel A of Table 10 presents the number of incidences of delinquent, overdue, and extended loans by 2013; it also shows the distribution of these cases between affiliated and nonaffiliated loans. There are a total of 194 such cases; 130 for affiliated loans and 64 for nonaffiliated loans. Thus, the percentage of problematic affiliated loans is smaller than that of nonaffiliated loans ( $7.3 \%$ versus $13.9 \%)$, again confirming that affiliated loans are less risky. When there is a problem, a higher proportion of affiliated loans are extended $(88 \%)$ than nonaffiliated loans 
(70\%). Panel A also reports the average loan amount for each type of problematic loan. The average amounts for delinquent, overdue, and extended loans are 51, 99, and 139 million RMB, respectively. The average amount for nonproblematic loans is 229 million RMB. This suggests that (1) lenders tend to lend smaller amounts to riskier borrowers, and (2) when large amounts are involved, lenders may have more incentive to extend the loans. ${ }^{18}$

Panel B of Table 10 compares the adjusted interest rate between problematic and nonproblematic loans. For the subsample of nonaffiliated loans, the ex ante interest rates are higher for problematic loans than for nonproblematic loans. The average adjusted interest rate for loans that are overdue and extended are $10.2 \%$ and $10.9 \%$, respectively. In contrast, the average adjusted rate for nonproblematic loans is $7.8 \%$. The difference in rates is statistically significant between each group of problematic loans and the nonproblematic loans.

These differences are absent for affiliated loans. The average adjusted interest rate for loans that are delinquent, overdue, or extended are $0.5 \%,-0.1 \%$, and $0.6 \%$, respectively. None is significantly different from the rate for nonproblematic loans, which is $0.3 \%$. This suggests that the pricing of the affiliated loans, although taking into account borrowers' risk to some extent, does not incorporate risk in a full and efficient way.

We next estimate multivariate logit regressions to examine the determinants of loan performance. The dependent variable is a dummy equal to 1 if the loan is delinquent, overdue, or extended. Our main variable of interest is the adjusted interest rate. We also control for other loan characteristics, borrower characteristics, and lender characteristics, as in Table 9. For borrower-

\footnotetext{
${ }^{18} \mathrm{We}$ also gauge the loss ratio of entrusted loans. The 194 loans that are delinquent, overdue or extended involve RMB 25 billion (out of 466 billion total loan amount). By examining these lending firms' subsequent annual reports, we find that in most of these cases, the lenders received full payments in the end. The exceptions are: in five cases the lenders lost RMB 0.15 billion, out of 0.21 billion loan amount; another 17 loans (involving a total of RMB1.66 billion) are still in the middle of lawsuits or waiting for the verdicts being executed, and their lenders took impairment provisions of 1.28 billion in aggregate. Based on these numbers, the total loss of the entrusted loans in our sample is 1.43 billion $(=1.28+0.15)$, which is $0.31 \%$ of total loan amount $(0.57 \%$ for nonaffiliated loans, and $0.29 \%$ for affiliated loans). In comparison, we looked up the item of "impairment losses on loans" from the income statements of listed banks for the period 2004-2013. The average loan loss ratio for banks is $0.61 \%$. Hence entrusted loans have lower loss ratios.
} 
industry risk, we use the industry-median return volatility. Our main results are robust if we use industry sales growth dispersion or a real-estate borrower dummy.

Table 11 reports the regression results for nonaffiliated loans (Column 1) and affiliated loans (Column 2). Consistent with the univariate results, Column 1 of Table 11 shows that for nonaffiliated loans, the adjusted interest rate is positively related to the likelihood of the loan being extended, overdue, or delinquent. The coefficient on the adjusted rate is positive and significant at the $1 \%$ level. Given that all other explanatory variables are at their means, when the adjusted interest rate increases from its 25 th percentile to 75 th percentile, the probability of a delinquent, overdue, or extended loan increases from $10.5 \%$ to $18.5 \%$. Thus the interest rate of nonaffiliated loans strongly predicts future loan performance. This is consistent with the notion that riskier loans are charged with a higher interest rate ex ante and end up with more defaults ex post.

Furthermore, Column 1 shows that after including the interest rate, borrowers' characteristics mostly have no predictive power for loan performance. This indicates that the interest rate has incorporated the risk information contained in these variables. Thus, nonaffiliated loans are priced in a fairly efficient way. One exception is same-city dummy, which has a significantly negative coefficient, suggesting that the likelihood of problematic loans is smaller if the lender and the borrower are in the same city. In untabulated results, we observe that $7.5 \%$ of same-city nonaffiliated loans turn out to be problematic, whereas the ratio more than doubles for nonaffiliated loans across cities $(20.8 \%)$. This is consistent with the notion that there is less information asymmetry if lenders and borrowers are in the same geographic location. When in the same city, a lender is better at screening borrowers, enforcing the loan payment, or both. Although same-city loans receive lower interest rates (Table 9), Table 11 suggests that the interest rate still under-reacts to the location-related information.

Column 2 presents strikingly different results for affiliated loans. The adjusted interest rate has no predictive power for loan performance. This suggests that the pricing of this type of loan 
does not incorporate risk information sufficiently. Again, this is consistent with the notion that affiliated loans are not driven by short-term profits but to support affiliated parties.

\subsection{The role of loan trustees}

An entrusted loan involves a bank or a nonbank financial company as a servicing agent. The agent is called a trustee. In principle, the trustee is not responsible for matching a lender with a borrower, does not provide any guarantee to the loan payment, and therefore does not bear any investment risk. It is possible that some financial firms have more incentives to channel entrusted loans than others. Chen, Ren, and Zha (2016) find that in response to tighter monetary policies, banks, especially small banks due to their sensitivity to policy changes, will channel more entrusted loans than nonbank financial firms. We examine whether the identity of the trustees affect answers to the research questions we focus on.

We hand-collect trustee names from lenders' annual reports and interim announcements; however, trustee information is not always disclosed. We are able to collect this information for 1,516 loans (out of the original sample of 2,960 loans). In comparison, Chen et al. (2016) examine 644 entrusted loans made by listed firms that have interim announcements.

Like Chen et al. (2016), we classify trustees into three types: big5 banks, small banks, and nonbank trustees. Big5 banks refers to the five largest state-owned commercial banks: Industrial and Commercial Bank of China, the Bank of China, the Construction Bank of China, the Agricultural Bank of China, and the Bank of Communications. Their combined share of total bank deposits was $49 \%$ in 2013 . Small banks include all other banks that are not part of the big5 group. ${ }^{19}$ Most nonbank trustees are the financial branches of conglomerate firms; they mainly facilitate affiliated loans. We observe that the percentages of nonaffiliated loans facilitated by big5 banks,

\footnotetext{
${ }^{19}$ More specifically, commercial banks in China can be categorized into four types: (1) the big five banks; (2) seven additional national banks; (3) more than 1,000 regional, city, and rural banks; and (4) dozens of private and foreign banks. The twelve national banks are all joint-stock banks controlled by the state. Most of the regional, city and rural banks are also majority-owned by the state. Our results hold if we define the 12 national joint-stock banks as big banks and the others as small banks.
} 
small banks, and nonbank trustees are $42 \%, 55 \%$, and $3 \%$ respectively; the respective numbers for affiliated loans are $28 \%, 42 \%$, and $30 \% .^{20}$

Taking into account the role of trustees, we redo all of our loan-level analyses. For summary statistics, we redo the analyses for subsamples based on the type of trustee. For regression analyses, we include two additional dummy variables: big5 banks and small banks. We do not find systematic differences in industry or geographic distribution of loans or in lender, borrower and loan characteristics.

We re-estimate the regressions in Tables 9 (determinant of loan rate) and 11 (predicting loan performance) after adding the big5 and small bank dummies. The tables show that the coefficients of the bank dummies are generally not statistically significant in the regressions of loan rate, suggesting that the type of trustee does not affect loan pricing. We do find positive coefficients for both bank dummies in predicting problematic performance of nonaffiliated loans, which is due to the fact that only 10 out 387 nonaffiliated loans (3\%) are channeled by nonbank trustees and none of those 10 observations were problematic. If we only include big5 banks but not small banks, its coefficient is not significant, suggesting bank type cannot predict loan performance. More importantly, our previous main results all hold. That is, loan rates depend on borrowers' risk, and loan rate can predict the performance of nonaffiliated loans. (Results are available upon request.) The evidence suggests that the research questions we focus on do not depend on the type of trustees.

In short, the evidence in this section suggests that the pricing of both types of loan depends on borrower risk; however, the rate of nonaffiliated loans incorporates risk in a more efficient way.

\footnotetext{
${ }^{20}$ Despite the sample-size difference, the distribution of trustees in our sample is similar to Chen et al. (see their Table 3 ). We are also able to replicate their main results. That is, in response to monetary tightening (measured by growth in M2), banks increase entrusted lending more than nonbank trustees, and small banks increase entrusted lending more than large banks.
} 


\section{Wealth effects of entrusted loans}

In this section we analyze the value consequence of the entrusted loans to the lenders. We have shown that nonaffiliated entrusted loans charge much higher interest rates than affiliated loans and that the affiliated loan rates are much lower than the market rate. This evidence alone, however, does not imply that nonaffiliated loans create value and affiliated loans destroy value. The lower-than-market rates of affiliated loans can be a form of long-term investment in affiliated parties rather than inefficient cross-subsidization. Nonaffiliated loans may create value, destroy value, or receive fair compensation depending on whether the interest rates are high enough for the risk.

To address the question whether entrusted loans create value, we examine the stock market reactions to the loan announcement, assuming the market is efficient in incorporating the value consequence. For this analysis, we focus on the 547 cases (358 affiliated loans and 189 nonaffiliated loans) where the lending firms announced the loans before their annual reports. There is a sample selection issue since not all firms make entrusted loan announcements. We describe and address this issue in multivariate regressions below. We estimate the cumulative abnormal returns (CARs) around the announcement based on the market model, using the index return of stocks traded on the Shanghai and Shenzhen stock exchanges as the market proxy and the trading days $[-150,-10]$ as the estimation period, where day 0 is the announcement day.

We first examine whether the announcement returns are significantly different from zero. If they are not, it suggests that these deals neither create nor destroy value, i.e., they are on average zero-NPV investments. If CARs are significantly positive (negative), there are two possibilities. One possibility is that these loans do create (destroy) values. Alternatively, these loans do not create (or destroy) values, but the fact that the lenders are making these loans can reveal to the market new positive (negative) information about the lenders. To distinguish the value-creation versus the information-revelation hypothesis, we divide the loans into two groups; firms' first announcements versus subsequent announcements, depending on whether it is the first time a firm 
announces such a loan during our sample period. If the abnormal returns are concentrated in firms' first loans only, then they are more likely due to information revelation as opposed to value creation. In contrast, the value-creation hypothesis predicts that the abnormal returns should be present in first and subsequent loans.

Table 12 Panel A presents the mean CARs for affiliated loans and nonaffiliated loans separately. We compute CARs for three time windows, trading days $[-1,1],[-3,3]$, and $[-5,5]$ around the loan announcement, where day 0 is the announcement day. The results are consistent for all three CAR measures; the mean CAR is not statistically significant for affiliated loans and significantly negative for nonaffiliated loans. This suggests that affiliated loans neither create nor destroy value, but instead are zero-NPV investments. Despite their lower-than-market interest rates, investors view them not as inefficient subsidization but as a form of investment that receives fair compensation in the future. In contrast, the negative CARs for nonaffiliated loans suggest that this type of loan either destroys value or conveys negative information about the lender. ${ }^{21}$

We next divide each type of affiliated and nonaffiliated loan into firms' first versus subsequent loan announcements. For affiliated loans, there are no significant differences between the two groups of transactions. For nonaffiliated loans, only the first announcements exhibit negative CARs. Subsequent announcements are associated with nonsignificant and near-zero CARs: the differences between the two groups are all significant at the 5\% level. Take the mean CARs around days $[-5,5]$, for example. The average CAR for all nonaffiliated loans is $-1.39 \%$, significant at the $10 \%$ level. The mean for firms' first nonaffiliated loan is $-3.78 \%$, significant at the $1 \%$ level, whereas the mean for subsequent nonaffiliated loans is a nonsignificant $0.33 \%$; the difference with

\footnotetext{
${ }^{21}$ Chen, Jiang, Ljungqvist, Lu, and Zhou (2015) document evidence that state-owned business groups tend to allocate capital to units with low investment opportunities, whereas private groups do the opposite. Our sample differs from theirs. Instead of studying business groups with the same ultimate controlling shareholder, we examine affiliated loans that are mostly between listed parent firms and subsidiaries; the motives and results of support can be very different. We do examine whether affiliated loans made by non-SOE lenders create more values than those made by SOE lenders. We find some evidence consistent with this conjecture. Specifically, the 3-day, 5-day, and 11-day announcement returns for non-SOE lenders are $0.05 \%, 0.99 \%$, and $1.20 \%$, respectively, and the respective numbers for SOE lenders are $0.20 \%, 0.11 \%$, and $0.21 \%$. However, none of the differences between the two groups are statistically significant.
} 
that of first loans is significant at the $1 \%$ level. The fact that the negative CAR is concentrated in firms' first announcements of nonaffiliated loans is consistent with the information-revelation hypothesis. That is, upon learning of a firm's making nonaffiliated loans, investors realize that the firm lacks good investment opportunities in their main businesses. On the other hand, the loans themselves do not destroy value, as evidenced by nonsignificant CARs for subsequent similar transactions.

Next, we estimate multivariate regressions of CARs. We include a firm's first announcement - a dummy equal to one if it is the first time it announces an entrusted loan —in the regression because the univariate results show this factor to be important. In addition, the abnormal returns may also depend on the terms of the loans. So we include $\log (\operatorname{loan}$ amount), adjusted interest rate, maturity, and the dummy for collateral or guarantee.

We note there is a selection issue in examining the announcement returns since not all firms make such announcements. Instead, many make the required disclosure in their annual reports along with other important disclosures, such as earnings announcements. The regulatory requirement on making entrusted loan announcements is vague: firms need to make announcements for "material" investments and events, but there is no technical definition of what is considered material. To address this, we investigate whether the choice of loan announcement depends on loan amount and lender characteristics. We then run a two-stage Heckman test, where the first stage is a logit regression of whether or not a loan announcement is made, and the second stage is a regression of CARs.

Table 12 Panel B reports the regression of CARs for affiliated and nonaffiliated loans. The dependent variable is the 11-day CAR. Results are similar if we use the 3-day or 7-day CARs. We report both the OLS and the Heckman second-stage regression results, which yield similar results. For nonaffiliated loans, the most important determinant of CARs is the dummy of a firm's first announcement. It has a highly significant and negative coefficient, suggesting that firms' first nonaffiliated loan announcements are associated with much more negative abnormal returns - a 
finding consistent with the univariate results. Consistent with the notion that these loan terms are endogenously chosen, we find no evidence that loan characteristics such as loan amount or interest rate have a significant impact on market reactions. For affiliated loans, the only coefficient significant at the conventional levels is that on a firm's first announcement in the OLS regression. The significance disappears in the Heckman regression. The regression results are robust if we include the dummies big5 banks and small banks. The coefficients of the bank dummies are not statistically significant, suggesting the type of trustee is not related to announcement returns.

The bottom portion of Panel B displays the results of the Heckman first-stage regressions for affiliated and nonaffiliated loans, respectively. For both types of loan, we observe that the likelihood of loan announcements increases with the loan amount and decreases with the firm size in terms of assets. This makes sense since the larger the loan size relative to the lender's asset value the more "material" the transaction is. In addition, for affiliated loans, SOE lenders are less likely to make announcements.

In summary, the results in this section suggest that both affiliated and nonaffiliated loans are fairly-compensated investments. Despite the lower-than-market interest rates, affiliated loans do not destroy value. Firms' first nonaffiliated loans reveal lenders' poor investment opportunities in their main businesses, to which investors respond negatively.

\section{Conclusions}

We conduct a large-sample transaction-level study of China's shadow banking system. Specifically, we examine the entrusted loans made by listed firms. These nonfinancial firms engage in entrusted loans because they can take advantage of their privileged access to the official financing system (such as bank loans and the stock market) to provide credit to less privileged firms. The likelihood and the amount of entrusted loans increase when credit is tight in the economy. Thus these loans are market reactions to credit shortage.

Affiliated and nonaffiliated loans have different motives. Lenders of affiliated loans are highly 
profitable and use the loans to support their subsidiaries, suppliers, or customers. In contrast, lenders of nonaffiliated loans suffer low growth rates and use the loans as an alternative investment channel to boost their earnings.

Consistent with the different motives, there are striking differences between the two loan types. First, nonaffiliated loans charge the market interest rate, which is about twice the official bank loan rate, whereas the average rate for affiliated loans is close to the official rate. This shows the official banking system is significantly distorted. Second, most affiliated loans are withinindustry loans, whereas close to half of the nonaffiliated loans flow into real estate and construction, an industry that regulators try to restrict capital from reaching. Third, we find evidence that the pricing of both types of loan depends on borrowers' fundamental and information risks; however, the rates of nonaffiliated loans incorporates risk more efficiently.

Finally, our investigation of announcement returns suggests that both affiliated and nonaffiliated loans are fairly compensated investments. Thus, the lower-than-market interest rates of affiliated loans are viewed as a form of investment rather than inefficient subsidization. 


\section{Appendix A: Examples of entrusted loan data collection}

China Securities Regulatory Commission (CRSC) stipulates that all listed firms disclose in audited annual reports the entrusted loans they make. We search for the keyword "entrusted loan" in all annual reports of listed nonfinancial firms during the period 2004-2013. We identify the lender and the borrower and record loan characteristic information. We make sure each observation is a newly originated loan. Firms also make interim announcements about entrusted loans when the loans are deemed material investments. We collect all the interim announcements about entrusted loans during the sample period. We use these announcements to cross-check and supplement information from annual reports.

In 2011, CRSC specified that entrusted loans should be disclosed in the section of an annual report called "The Board's Report_-Investments Analysis." All loans since then have been listed in this section; however, some relevant information may still be found in other parts of the annual report.

\section{Example 1: Shantou Dongfeng Printing Inc.}

In its annual report for the year 2012, Shantou Dongfeng Printing published the following table in the section "The Board's Report - Investment Analysis - Entrusted Loans."

\begin{tabular}{|c|c|c|c|c|c|c|c|c|}
\hline Borrower & Amount & Maturity & Rate & Use of fund & $\begin{array}{l}\text { Collateral or } \\
\text { guarantee }\end{array}$ & $\begin{array}{l}\text { Affiliated Overdue } \\
\text { loans }\end{array}$ & Extended & $\begin{array}{l}\text { Any legal } \\
\text { dispute }\end{array}$ \\
\hline $\begin{array}{l}\text { Nanjing } \\
\text { Chengwang Real } \\
\text { Estate Inc. }\end{array}$ & $\begin{array}{l}150 \mathrm{M} \\
\mathrm{RMB}\end{array}$ & $\begin{array}{l}24 \\
\text { months }\end{array}$ & $15 \%$ & $\begin{array}{l}\text { Real estate } \\
\text { development }\end{array}$ & $\begin{array}{l}\text { Nanjing } \\
\text { Chengwang's } \\
100 \% \text { equity }\end{array}$ & No & No & No \\
\hline $\begin{array}{l}\text { Guangxi Baide } \\
\text { Real Estate Inc. }\end{array}$ & $\begin{array}{l}150 \mathrm{M} \\
\mathrm{RMB}\end{array}$ & $\begin{array}{l}24 \\
\text { months }\end{array}$ & $15 \%$ & $\begin{array}{l}\text { Real estate } \\
\text { development }\end{array}$ & $\begin{array}{l}\text { Guangxi } \\
\text { Baide's 100\% } \\
\text { equity }\end{array}$ & No & No & No \\
\hline
\end{tabular}

The related paragraphs explain that the company used its extra cash to provide entrusted loans to Nanjing Chengwang Real Estate Inc. and Guangxi Baide Real Estate Inc. The trustee for both loans is China Minsheng Bank Shantou Branch. Neither the company nor its insiders - the controlling shareholder, $5 \%$ blockholders, directors, supervisors, and top manager-had business affiliations with either of the borrowers. Thus both loans are nonaffiliated loans.

The company also discloses both entrusted loans in a footnote to the balance sheet item "other long term assets." The loan agreement with Nanjing Chengwang Real Estate was signed on December 3, 2012, with a loan period from December 6, 2012, to December 6, 2014. The annual interest rate was $15 \%$. The loan agreement with Guangxi Baide Real Estate was signed on December 14, 2012, with a loan period from December 17, 2012, to December 17, 2014. The annual interest rate was $15 \%$.

The company made respective public announcements about the loans on December 1, 2012, and Dec 15, 2012. The announcements confirm information in the annual report, and contain additional information about the borrowers. Nanjing Chengwang Real Estate is a real estate company located in Nanjing, Jiangsu Province. It had total assets of 966.75 million RMB as of September 30, 2012. Guangdon Chengwang is the parent company of the borrower and holds $100 \%$ of its shares. Two individuals, Wang Man and Wang Chun, each own $50 \%$ of the parent company. Thus Nanjing Chengwang is a non-SOE firm. Guangxi Baide Real Estate is a real estate company located in Nanning, Guangxi Province. It had total assets of 91.11 million RMB as of September 30, 2012. Shanghai Chengwang is the parent company of the borrower and holds $100 \%$ of its shares. Two individuals, Wang Man and $\mathrm{Ma} \mathrm{Si}$, own $90 \%$ and $10 \%$ of the parent company, respectively. Thus Guangxi Baide is also a non-SOE firm. 
In Shantou Dongfeng's annual report for the year 2013, we find the same disclosure about the loans in both the section "The Board's Report - Investment Analysis" and the section "Footnote - other long term assets." We do not treat these loans as new loans in 2013.

\section{Example 2: Gemdale Corporation}

In Gemdale Corporation's annual report for the year 2006, a footnote to the balance-sheet item "long term debt investment" reports that the company provided an entrusted loan of 253.23 million RMB to Shanghai CRED Real Estate Inc. The loan period was from Dec 27, 2006, to Dec 26, 2008. The annual interest rate is $6.3 \%$. The purpose of the loan is for real-estate development of two pieces of land. The borrower uses the two pieces of land as the collateral.

In the section "The Board's Report-Daily Operations," Gemdale discloses that it will develop two pieces of land with the borrower and provided the borrower an entrusted loan. The additional information reveals that the lender and the borrower are business partners. We therefore classify this loan as an affiliated loan.

\section{Example 3: Shenzhen Tianma Microelectronics Inc.}

In Shenzhen Tianma Microelectronics Inc.'s annual report for the year 2008, we find information about an entrusted loan in the section "Corporate Governance-Related Party Transactions." The board approved a one-year entrusted loan of 150 million RMB to Shanghai Tianma Microelectronics Co. at an interest rate set at $10 \%$ above the benchmark rate of commercial banks. We calculate the rate using 1.1 times the benchmark rate.

We find similar information in the section "Financial Report-Internal Control EvaluationRelated Party Transactions" and cross-check the details.

We then search the name of the borrower, Shanghai Tianma Microelectronics, in the annual report. In the section "Board Report-Performance of Affiliated Firms," it is noted that Shenzhen Tianma Microelectronics Inc. owns $30 \%$ of the borrower. Thus we classify this loan as an affiliated loan.

In a public announcement dated on Sept 25, 2008, we find the following additional information: the industry of the borrower, the use of the loan, and the fact that there is no collateral used for this loan. 
Appendix B: Variable Definitions

A firm's first
announcement
Adjusted interest rate (\%)

Affiliated loan

Assets (billion RMB)

Borrower industry return volatility high

Borrower industry sales growth dispersion high

Cash/assets (\%)

CAR $[-5,+5](\%)$

Change of debt (\%)

Collateral

Collateral or Guarantee

Debt/assets (\%)

Delinquent or overdue or extend dummy

\section{Guarantee}

Shibor (\%)

Firm age

Loan amount (Million $R M B)$

Loan amount/assets (\%)

Loan dummy

Maturity (Month)
A dummy equal to one if it is the first time a firm announces an (affiliated or nonaffiliated) entrusted loan, and zero otherwise

A loan's interest rate minus the official bank lending rate of same maturity

A dummy equal to one if a firm made a loan to an affiliated party, and zero otherwise

Total assets at the beginning of the year when the loan is made, adjusted to constant year 2013 RMBs

A dummy equal to one if the industry return volatility is above median during the year before the loan is made. Industry return volatility is computed as the median of the standard deviations of daily returns for firms in the borrower industry

A dummy equal to one if the industry sales growth dispersion is above median during the year before the loan is made. Sales growth dispersion is computed as the standard deviation of sales growth of firms in the borrower industry

The ratio of cash to assets at the beginning of the year when the loan is made

The cumulative abnormal return 11 days around the loan announcement, calculated based on the market model. The estimation period for the market model is during trading days $[-150,-10]$, where day 0 is the announcement day

Change of total debt in year $t-1$, divided by the average of assets at the beginning and the end of the year, where year $t$ is the year in which the loan is made

A dummy equal to one if a loan requires collateral, and zero otherwise

A dummy equal to one if a loan requires collateral or third-party guarantee, and zero otherwise

The ratio of total debt to assets at the beginning of the year when the loan is made

A dummy equal to one if a loan is delinquent, overdue, or extended, and zero otherwise

A dummy equal to one if a loan requires third-party guarantee, and zero otherwise

The daily average of China's official interbank offered rate in the year when the loan is made

The firm's age from the listed year to the year when the loan is made

The RMB amount of a loan, adjusted to constant year 2013 RMBs

The total loan amount a firm made during a year, divided by firm assets at the beginning of the year when the loan is made

A dummy equal to one if a firm made a loan in a certain year, and zero otherwise

The maturity of a loan 
Ownership

Purpose of loan-debt retirement dummy

Purpose of loan-specified project dummy

Real estate borrower

Real estate lender

$R O A(\%)$

Sales growth (\%)

Same city

Same industry

SOE borrower

SOE lender

Tobin's $Q$

Trade relationship
The lender's equity ownership in the borrower (in decimals). This variable is only defined for affiliated loans.

A dummy equal to one if the stated purpose of a loan is for debt retirement, and zero otherwise

A dummy equal to one if the stated purpose of a loan is for a specific investment project, and zero otherwise

A dummy equal to one if the borrower is in the real estate and construction industry, and zero otherwise

A dummy equal to one if the lender is in the real estate and construction industry, and zero otherwise

Return on assets in the year before the entrusted loan is made

The sales growth rate in the year before the entrusted loan is made

A dummy equal to one if the borrower is in the same city as the lender, and zero otherwise

A dummy equal to one if the borrower is in the same industry as the lender, and zero otherwise

A dummy equal to one if the borrower is a state-owned enterprise, and zero otherwise

A dummy equal to one if the lender is a state-owned enterprise, and zero otherwise

Tobin's Q as of the beginning of the year when the loan is made

A dummy equal to one if the borrower is a customer, supplier, or joint-venture partner of the lender. This variable is only defined for affiliated loans. 


\section{References}

Acharya, V., Qian, J., Yang, Z., 2016. In the shadow of banks: wealth management products and issuing banks' risk in China. Draft paper, February 2016.

Allen F, Qian, J., 2014, China's financial system and the law, Cornell International Law Journal 47, 499-553.

Allen, F., Qian, M., Xie, J., 2018. Understanding informal financing. Journal of Financial Intermediation, forthcoming.

Berger, A., Udell, G., 1990. Collateral, loan quality, and bank risk. Journal of Monetary Economics 25, 21-42.

Berger, A., Udell, G., 1995. Relationship lending and lines of credit in small firm finance. Journal of Business 68, 351-381.

Buchuk, D., Larrain, B., Munoz, F., Urzua, F., 2014. The internal capital markets of business groups: Evidence from intra-group loans. Journal of Financial Economics 112, 190-212.

Chen, D., Jiang, D., Ljungqvist, A., Lu, H., Zhou, M., 2015. State capitalism vs. private enterprise. Unpublished Working paper.

Chen, Z., He, Z., and Liu, C., 2017. The Financing of local government in China: stimulus loan wanes and shadow banking waxes. Unpublished Working paper.

Chen K., Ren. J., Zha T., 2016. What we learn from China's rising shadow banking: exploring the nexus of monetary tightening and banks' role in entrusted lending. Unpublished Working paper.

Degryse, H., Ongena, S., 2005. Distance, lending relationships, and competition. Journal of Finance 60, 231-266.

Dennis, S., Nandy, D., Sharpe, I., 2000. The Determinants of contract terms in bank revolving credit agreements. Journal of Financial and Quantitative Analysis 35, 87-110.

Flannery, M., 1986. Asymmetric information and risky debt maturity choice. Journal of Finance 41, 18-38.

Gopalan, R., Nanda, V., Seru, A., 2007. Affiliated firms and financial support: Evidence from Indian business groups. Journal of Financial Economics 86, 759-795.

Hachem, K., Song, Z., 2016, Liquidity regulation and unintended financial transformation in China. Unpublished Working paper.

He, Q., Lu, L., Ongena, S., 2016, Who gains from credit granted between firms? Evidence from inter-corporate loan announcements made in China. Unpublished Working Paper.

International Monetary Fund, 2014, IMF Country Report No. 14/235 People's Republic of China.

Jiang, G., Lee, C.M.C., Yue, H. 2010. Tunneling through intercorporate loans: the China experience. Journal of Financial Economics 98, 1-20.

La Porta, R., Lopez-de-Silanes, F., Zamapripa, G., 2003. Related lending. The Quarterly Journal of Economics, February, 231-268.

Mian, A., 2006. Distance Constraints: The limits of foreign lending in poor economies. Journal of Finance 61, 1465-1505.

Moody's, 2013. Risks to China's lenders from shadow banking: Frequently Asked Questions.

Moody's, 2016. Quarterly China shadow banking monitor.

Moody's, 2017. Quarterly China shadow banking monitor.

Petersen, M.A., Rajan, R.G., 1994. The benefits of lending relationships: evidence from small business data. Journal of Finance 49, 3-37.

Song, Z., Storesletten, K., Zilibotti, F., 2011. Growing like China. American Economic Review 101(1), 196-233.

Wang, H., Wang, H., Wang, L., Zhou, H., 2016. Shadow banking: China's dual-track interest rate liberalization. Working paper.

Wei, L., Davis, B., 2014, Regulators at odds on reining in China's shadow lending, Wall Street Journal. 
Wu, J., Gyourko, J., Deng, Y., 2012. Evaluating conditions in major Chinese housing markets. Regional Science and Urban Economics 42, 531-543.

Yu, Y., Lee, Y., Fok, C., 2015. Speculative motive for holding cash and high-interest entrusted loans. Unpublished Working paper. 


\section{Table 1}

Entrusted loans over time

The sample includes 2,995 entrusted loans during the period 2004-2013. All RMB values are adjusted to constant year 2013 RMBs.

\begin{tabular}{lccccccccccc}
\hline & 2004 & 2005 & 2006 & 2007 & 2008 & 2009 & 2010 & 2011 & 2012 & 2013 & Total \\
\hline Number of firms that & 55 & 51 & 53 & 65 & 99 & 95 & 116 & 176 & 177 & 220 & 1,107 \\
$\quad$ make entrusted loans & 116 & 98 & 102 & 151 & 209 & 208 & 280 & 530 & 626 & 675 & 2,995 \\
$\begin{array}{c}\text { Number of entrusted loans } \\
\text { Aggregate loan amount }\end{array}$ & 12.6 & 9.3 & 12.6 & 23.6 & 38.2 & 32.5 & 41.1 & 100.5 & 202.2 & 219.2 & 691.8 \\
\begin{tabular}{c} 
(Billion RMB) \\
\hline
\end{tabular}
\end{tabular}




\section{Table 2}

Summary statistics

The sample includes the 18,003 firm-year observations for all the listed nonfinancial Chinese firms during the period 2004-2013. Variable definitions are in Appendix B. All RMB values are adjusted to constant year 2013 RMBs. Continuous variables are winsorized at $1 \%$ and $99 \%$. We use t-test for differences in means. $* * *, * *$, and $*$ denote the difference is significant at the $1 \%, 5 \%$, and $10 \%$ levels, respectively.

\begin{tabular}{lcccccccc}
\hline & $\begin{array}{c}\text { Loan } \\
\text { dummy=0 } \\
(n=16,896)\end{array}$ & $\begin{array}{c}\text { Loan } \\
\text { dummy=1 } \\
(n=1,107)\end{array}$ & $\begin{array}{c}\text { Nonaffiliated } \\
\text { loan } \\
(n=289)\end{array}$ & $\begin{array}{c}\text { Affiliated } \\
\text { loan } \\
(n=800)\end{array}$ & $(2)-(1)$ & $(3)-(1)$ & $(4)-(1)$ & $(4)-(3)$ \\
\hline Assets (billion RMB) & 5.8 & 18.1 & 10.6 & 21.0 & $12.3^{* * *}$ & $4.8^{* * *}$ & $15.2^{* * *}$ & $10.4^{* * *}$ \\
ROA (\%) & 6.9 & 7.6 & 7.4 & 7.6 & $0.7^{* * *}$ & 0.5 & $0.7^{* *}$ & 0.2 \\
Sales growth (\%) & 23.6 & 24.4 & 18.0 & 26.5 & 0.8 & $-5.6^{*}$ & 2.9 & $8.5^{* *}$ \\
Firm age & 8.1 & 9.8 & 9.5 & 9.9 & $1.7^{* * *}$ & $1.4^{* * *}$ & $1.8^{* * *}$ & 0.4 \\
Tobin's $Q$ & 1.8 & 1.6 & 1.7 & 1.6 & $-0.2^{* * *}$ & -0.1 & $-0.2^{* * *}$ & -0.1 \\
Debt/assets (\%) & 20.7 & 21.6 & 16.7 & 23.5 & $0.9^{*}$ & $-4.0^{* * *}$ & $2.8^{* * *}$ & $6.8^{* * *}$ \\
Change of debt (\%) & 4.0 & 7.8 & 5.0 & 8.7 & $3.8^{* * *}$ & 1.0 & $4.7^{* * *}$ & $3.7^{* * *}$ \\
Cash/assets (\%) & 19.4 & 18.4 & 21.4 & 17.2 & $-1.0^{* *}$ & $2.0^{* *}$ & $-2.2^{* * *}$ & $-4.2^{* * *}$ \\
SOE lender (\%) & 54.6 & 73.8 & 56.7 & 79.9 & $19.2^{* * *}$ & 2.1 & $25.3^{* * *}$ & $23.2^{* * *}$ \\
Real estate lender (\%) & 8.4 & 10.4 & 7.3 & 11.8 & $2.0^{* *}$ & -1.1 & $3.4^{* * *}$ & $4.5^{* *}$ \\
\hline
\end{tabular}




\section{Table 3}

Determinants of loan decisions

The sample includes the 18,003 firm-years observations for all the listed nonfinancial Chinese firms during the period 2004-2013. We run logit regressions using Loan dummy as the dependent variable, and we run Tobit regressions using Loan amount/assets (\%) as the dependent variable. Variable definitions are in Appendix B. Financial variables are winsorized at 1\% and $99 \%$. $p$-values are based on standard errors double-clustered by firm and year. $* * *, * *$, and $*$ denote significance at the $1 \%, 5 \%$, and $10 \%$ levels, respectively.

\begin{tabular}{|c|c|c|c|c|c|c|}
\hline \multicolumn{7}{|c|}{ Panel A: Regressions with year fixed effects } \\
\hline & \multicolumn{3}{|c|}{ Logit regression: Loan Dummy } & \multicolumn{3}{|c|}{ Tobit regression: Loan amount/assets (\%) } \\
\hline & $\begin{array}{l}\text { (1) } \\
\text { All firm- } \\
\text { years }\end{array}$ & $\begin{array}{c}(2) \\
\text { Firm-years with } \\
\text { nonaffiliated } \\
\text { loans and } \\
\text { without } \\
\text { entrusted loans }\end{array}$ & $\begin{array}{c}(3) \\
\text { Firm-years } \\
\text { with affiliated } \\
\text { loans and } \\
\text { without } \\
\text { entrusted loans }\end{array}$ & $\begin{array}{l}(4) \\
\text { All firm- } \\
\text { years }\end{array}$ & $\begin{array}{c}(5) \\
\text { Firm-years with } \\
\text { nonaffiliated } \\
\text { loans and } \\
\text { without } \\
\text { entrusted loans }\end{array}$ & $\begin{array}{c}(6) \\
\text { Firm-years } \\
\text { with affiliated } \\
\text { loans and } \\
\text { without } \\
\text { entrusted loans }\end{array}$ \\
\hline Ln(assets) & $\begin{array}{l}0.48^{* * *} \\
(0.00)\end{array}$ & $\begin{array}{l}0.38 * * * \\
(0.00)\end{array}$ & $\begin{array}{l}0.49^{* * *} \\
(0.00)\end{array}$ & $\begin{array}{l}3.12 * * * \\
(0.00)\end{array}$ & $\begin{array}{l}2.62 * * * \\
(0.00)\end{array}$ & $\begin{array}{l}3.09^{* * *} \\
(0.00)\end{array}$ \\
\hline$R O A(\%)$ & $\begin{array}{r}0.01 \\
(0.12)\end{array}$ & $\begin{array}{r}0.007 \\
(0.60)\end{array}$ & $\begin{array}{l}0.013^{* *} \\
(0.05)\end{array}$ & $\begin{array}{l}0.08^{* * * *} \\
(0.00)\end{array}$ & $\begin{array}{r}0.07 \\
(0.20)\end{array}$ & $\begin{array}{l}0.08 * * * \\
(0.00)\end{array}$ \\
\hline Sales growth (\%) & $\begin{array}{l}-0.001 * * \\
(0.03)\end{array}$ & $\begin{array}{l}-0.004 * * * \\
(0.01)\end{array}$ & $\begin{array}{r}-0.001 \\
(0.20)\end{array}$ & $\begin{array}{l}-0.02 * * \\
(0.02)\end{array}$ & $\begin{array}{l}-0.03^{* * *} \\
(0.00)\end{array}$ & $\begin{array}{l}-0.01 \\
(0.25)\end{array}$ \\
\hline Ln(Firm age) & $\begin{array}{l}0.20^{* *} \\
(0.03)\end{array}$ & $\begin{array}{l}0.33^{*} \\
(0.06)\end{array}$ & $\begin{array}{r}0.13 \\
(0.18)\end{array}$ & $\begin{array}{l}1.79^{* * * *} \\
(0.00)\end{array}$ & $\begin{array}{l}2.77 * * * \\
(0.00)\end{array}$ & $\begin{array}{l}1.02 * \\
(0.06)\end{array}$ \\
\hline Tobin's $Q$ & $\begin{array}{l}-0.02 \\
(0.63)\end{array}$ & $\begin{array}{l}-0.08 \\
(0.25)\end{array}$ & $\begin{array}{l}-0.01 \\
(0.85)\end{array}$ & $\begin{array}{r}0.01 \\
(0.92)\end{array}$ & $\begin{array}{l}-0.49 \\
(0.16)\end{array}$ & $\begin{array}{l}0.20^{* * *} \\
(0.00)\end{array}$ \\
\hline Debt/assets (\%) & $\begin{array}{l}-0.01 \\
(0.12)\end{array}$ & $\begin{array}{l}-0.02 * * * \\
(0.00)\end{array}$ & $\begin{array}{r}-0.001 \\
(0.86)\end{array}$ & $\begin{array}{l}-0.07 * * * \\
(0.00)\end{array}$ & $\begin{array}{l}-0.16^{* * *} \\
(0.00)\end{array}$ & $\begin{array}{l}-0.02 \\
(0.31)\end{array}$ \\
\hline Change of debt (\%) & $\begin{array}{l}0.01 \text { *** } \\
(0.00)\end{array}$ & $\begin{array}{r}0.005 \\
(0.14)\end{array}$ & $\begin{array}{l}0.01 * * * \\
(0.00)\end{array}$ & $\begin{array}{l}0.09^{* * * *} \\
(0.00)\end{array}$ & $\begin{array}{r}0.05 \\
(0.14)\end{array}$ & $\begin{array}{l}0.08^{* * * *} \\
(0.00)\end{array}$ \\
\hline Cash/assets (\%) & $\begin{array}{r}0.006 \\
(0.24)\end{array}$ & $\begin{array}{r}0.004 \\
(0.58)\end{array}$ & $\begin{array}{r}0.005 \\
(0.32)\end{array}$ & $\begin{array}{l}0.06^{* * *} \\
(0.00)\end{array}$ & $\begin{array}{l}0.06^{* *} \\
(0.02)\end{array}$ & $\begin{array}{r}0.02 \\
(0.18)\end{array}$ \\
\hline SOE lender & $\begin{array}{l}0.37^{* * * *} \\
(0.01)\end{array}$ & $\begin{array}{l}-0.30 \\
(0.20)\end{array}$ & $\begin{array}{l}0.69^{* * *} \\
(0.00)\end{array}$ & $\begin{array}{l}2.27 * * * \\
(0.01)\end{array}$ & $\begin{array}{l}-2.49^{*} \\
(0.09)\end{array}$ & $\begin{array}{l}3.86^{* * *} \\
(0.00)\end{array}$ \\
\hline Year fixed effect & Yes & Yes & Yes & Yes & Yes & Yes \\
\hline Industry fixed effect & Yes & Yes & Yes & Yes & Yes & Yes \\
\hline$N$ & 18,003 & 17,185 & 17,696 & 18,003 & 17,185 & 17,696 \\
\hline Pseudo R2 & 0.11 & 0.09 & 0.14 & 0.05 & 0.06 & 0.07 \\
\hline
\end{tabular}




\begin{tabular}{|c|c|c|c|c|c|c|}
\hline \multicolumn{7}{|c|}{ Panel B: Regressions including Shibor } \\
\hline & \multicolumn{3}{|c|}{ Logit regression: Loan Dummy } & \multicolumn{3}{|c|}{ Tobit regression: Loan amount/assets (\%) } \\
\hline & $\begin{array}{c}(1) \\
\text { All firm- } \\
\text { years }\end{array}$ & $\begin{array}{c}(2) \\
\text { Firm-years with } \\
\text { nonaffiliated } \\
\text { loans and } \\
\text { without } \\
\text { entrusted loans } \\
\end{array}$ & $\begin{array}{c}(3) \\
\text { Firm-years } \\
\text { with affiliated } \\
\text { loans and } \\
\text { without } \\
\text { entrusted loans } \\
\end{array}$ & $\begin{array}{c}(4) \\
\text { All firm- } \\
\text { years }\end{array}$ & $\begin{array}{c}(5) \\
\text { Firm-years with } \\
\text { nonaffiliated } \\
\text { loans and } \\
\text { without } \\
\text { entrusted loans }\end{array}$ & $\begin{array}{c}(6) \\
\text { Firm-years } \\
\text { with affiliated } \\
\text { loans and } \\
\text { without } \\
\text { entrusted loans } \\
\end{array}$ \\
\hline Ln(assets) & $\begin{array}{l}0.50^{* * *} \\
(0.00)\end{array}$ & $\begin{array}{l}0.40^{* * *} \\
(0.00)\end{array}$ & $\begin{array}{l}0.52 * * * \\
(0.00)\end{array}$ & $\begin{array}{l}3.27^{* * *} \\
(0.00)\end{array}$ & $\begin{array}{l}2.79^{* * *} \\
(0.00)\end{array}$ & $\begin{array}{l}3.23^{* * *} \\
(0.00)\end{array}$ \\
\hline Shibor (\%) & $\begin{array}{l}0.25^{* * *} \\
(0.00)\end{array}$ & $\begin{array}{l}0.30^{* * *} \\
(0.00)\end{array}$ & $\begin{array}{l}0.24^{* * *} \\
(0.00)\end{array}$ & $\begin{array}{l}1.91^{* * *} \\
(0.00)\end{array}$ & $\begin{array}{l}2.37^{* * * *} \\
(0.00)\end{array}$ & $\begin{array}{l}1.67^{* * *} \\
(0.00)\end{array}$ \\
\hline$R O A(\%)$ & $\begin{array}{l}0.01 * \\
(0.09)\end{array}$ & $\begin{array}{l}0.006 \\
(0.64)\end{array}$ & $\begin{array}{l}0.014^{* *} \\
(0.03)\end{array}$ & $\begin{array}{l}0.09 * * * \\
(0.00)\end{array}$ & $\begin{array}{r}0.06 \\
(0.20)\end{array}$ & $\begin{array}{l}0.09 * * * \\
(0.00)\end{array}$ \\
\hline Sales growth (\%) & $\begin{array}{l}-0.002 * * * \\
(0.01)\end{array}$ & $\begin{array}{l}-0.004 * * * \\
(0.01)\end{array}$ & $\begin{array}{c}-0.001^{*} \\
(0.10)\end{array}$ & $\begin{array}{l}-0.02^{* * *} \\
(0.01)\end{array}$ & $\begin{array}{l}-0.03^{* * *} \\
(0.00)\end{array}$ & $\begin{array}{l}-0.01 \\
(0.21)\end{array}$ \\
\hline Ln(Firm age) & $\begin{array}{l}0.23^{* * *} \\
(0.01)\end{array}$ & $\begin{array}{l}0.35^{* *} \\
(0.04)\end{array}$ & $\begin{array}{l}0.18^{*} \\
(0.08)\end{array}$ & $\begin{array}{l}2.02 * * * \\
(0.00)\end{array}$ & $\begin{array}{l}2.94 * * * \\
(0.00)\end{array}$ & $\begin{array}{l}1.24 * * \\
(0.02)\end{array}$ \\
\hline Tobin's $Q$ & $\begin{array}{r}-0.004 \\
(0.91)\end{array}$ & $\begin{array}{l}-0.06 \\
(0.32)\end{array}$ & $\begin{array}{r}0.02 \\
(0.73)\end{array}$ & $\begin{array}{r}0.14 \\
(0.68)\end{array}$ & $\begin{array}{l}-0.36 \\
(0.22)\end{array}$ & $\begin{array}{r}0.35 \\
(0.34)\end{array}$ \\
\hline Debt/assets (\%) & $\begin{array}{l}-0.01 \\
(0.11)\end{array}$ & $\begin{array}{l}-0.02 * * * \\
(0.00)\end{array}$ & $\begin{array}{r}-0.001 \\
(0.87)\end{array}$ & $\begin{array}{l}-0.07^{* * *} \\
(0.00)\end{array}$ & $\begin{array}{l}-0.17 * * * \\
(0.00)\end{array}$ & $\begin{array}{l}-0.02 \\
(0.32)\end{array}$ \\
\hline Change of debt (\%) & $\begin{array}{l}0.01^{* * * *} \\
(0.00)\end{array}$ & $\begin{array}{l}0.005 \\
(0.11)\end{array}$ & $\begin{array}{l}0.01 * * * \\
(0.00)\end{array}$ & $\begin{array}{l}0.09 * * * \\
(0.00)\end{array}$ & $\begin{array}{l}0.05 \\
(0.13)\end{array}$ & $\begin{array}{l}0.08^{* * * *} \\
(0.00)\end{array}$ \\
\hline Cash/assets (\%) & $\begin{array}{r}0.007 \\
(0.18)\end{array}$ & $\begin{array}{r}0.005 \\
(0.51)\end{array}$ & $\begin{array}{r}0.007 \\
(0.23)\end{array}$ & $\begin{array}{l}0.06^{* * *} \\
(0.00)\end{array}$ & $\begin{array}{l}0.06 * * * \\
(0.01)\end{array}$ & $\begin{array}{l}0.03 * \\
(0.09)\end{array}$ \\
\hline SOE lender & $\begin{array}{l}0.33^{* * * *} \\
(0.01)\end{array}$ & $\begin{array}{l}-0.35 \\
(0.12)\end{array}$ & $\begin{array}{l}0.64 * * * \\
(0.00)\end{array}$ & $\begin{array}{l}1.90^{* *} \\
(0.02)\end{array}$ & $\begin{array}{l}-2.96^{* *} \\
(0.04)\end{array}$ & $\begin{array}{l}3.56^{* * *} \\
(0.00)\end{array}$ \\
\hline Industry fixed effect & Yes & Yes & Yes & Yes & Yes & Yes \\
\hline$N$ & 18,003 & 17,185 & 17,696 & 18,003 & 17,185 & 17,696 \\
\hline Pseudo R2 & 0.11 & 0.09 & 0.14 & 0.05 & 0.05 & 0.07 \\
\hline
\end{tabular}




\section{Table 4}

Interest rates

This table reports the average interest rate for nonaffiliated and affiliated loans, respectively, and by industry.

\begin{tabular}{|c|c|c|c|c|c|c|}
\hline \multirow[b]{2}{*}{ Industry of the borrower } & \multicolumn{3}{|c|}{ Nonaffiliated loans } & \multicolumn{3}{|c|}{ Affiliated loans } \\
\hline & $N$ & $\begin{array}{c}\text { Interest rate } \\
(\%)\end{array}$ & $\begin{array}{c}\text { Adjusted } \\
\text { interest rate } \\
(\%)\end{array}$ & $N$ & $\begin{array}{c}\text { Interest rate } \\
(\%)\end{array}$ & $\begin{array}{c}\text { Adjusted } \\
\text { interest rate } \\
(\%)\end{array}$ \\
\hline All sample & 587 & 13.9 & 7.9 & 2,373 & 6.4 & 0.3 \\
\hline Agriculture & 5 & 11.2 & 5.4 & 9 & 7.4 & 1.3 \\
\hline Auto \& auto parts & 3 & 9.4 & 3.0 & 211 & 5.2 & -0.8 \\
\hline Building materials & 11 & 10.1 & 4.4 & 50 & 6.0 & 0.2 \\
\hline Chemicals & 14 & 10.5 & 4.5 & 173 & 5.8 & -0.2 \\
\hline Coal \& mining & 5 & 9.2 & 3.3 & 155 & 6.3 & 0.1 \\
\hline Commerce & 39 & 13.4 & 7.5 & 20 & 6.5 & 0.4 \\
\hline Conglomerate & 88 & 12.5 & 6.6 & 18 & 7.9 & 1.7 \\
\hline Culture \& media & 7 & 9.5 & 3.6 & 1 & 6.2 & 0.0 \\
\hline Education, finance, and others & 15 & 11.0 & 5.1 & 7 & 7.3 & 1.3 \\
\hline Electrical household appliances & 12 & 14.8 & 8.8 & 32 & 6.5 & 0.4 \\
\hline Electronics \& IT & 11 & 12.9 & 6.8 & 80 & 6.3 & 0.2 \\
\hline Food & 9 & 15.7 & 9.7 & 154 & 5.5 & -0.6 \\
\hline Hotel \& tourism & 23 & 15.9 & 9.9 & 31 & 5.1 & -1.2 \\
\hline Machinery & 9 & 12.2 & 6.5 & 148 & 5.8 & -0.2 \\
\hline Nonferrous metal & 1 & - & - & 24 & 5.9 & 0.1 \\
\hline Other light industry & 9 & 11.6 & 5.6 & 4 & 7.1 & 0.9 \\
\hline Paper \& printing & 5 & 16.1 & 10.3 & 55 & 5.5 & -0.6 \\
\hline Pharmacy & 9 & 12.4 & 6.5 & 127 & 6.4 & 0.3 \\
\hline Real estate \& construction & 269 & 15.5 & 9.5 & 364 & 9.1 & 3.0 \\
\hline Steel & 8 & 11.8 & 5.8 & 27 & 5.9 & -0.0 \\
\hline Transportation & 26 & 11.4 & 5.4 & 230 & 5.6 & -0.4 \\
\hline Textile \& garment & 2 & 6.9 & 1.2 & 68 & 5.9 & -0.1 \\
\hline Utility & 7 & 11.1 & 5.0 & 385 & 6.0 & -0.1 \\
\hline
\end{tabular}




\section{Table 5}

Cost of borrowing for firms that make entrusted loans

The bond issuance data is from WIND. Panel A reports the adjusted cost of bonds (benchmarked against the official bank loan rate). Panel B compares these firms' cost of borrowing versus the rate they charge on the entrusted loans they make. *** denotes significance at the $1 \%$ level.

\begin{tabular}{lcccccc}
\hline \multicolumn{5}{l}{ Panel A: Lender's adjusted cost of bond $(\%)=$ Lender's cost of bond $(\%)-$ Official bank loan rate (\%) } \\
\hline All sample & $N$ & Mean & STD & $25^{\text {th }}$ perc & Median & $75^{\text {th }}$ perc \\
SOE lender & 244 & $-1.34 * * *$ & 1.34 & -2.02 & $-1.42^{* * *}$ & -0.53 \\
Non-SOE lender & 193 & $-1.52^{* * *}$ & 1.28 & -2.07 & $-1.55^{* * *}$ & -0.81 \\
SOE versus Non-SOE & 51 & $-0.64 * * *$ & 1.31 & -1.43 & $-0.50^{* * *}$ & 0.00 \\
\hline
\end{tabular}

Panel B: Interest rate difference (\%) = Adjusted interest rate of entrusted loan (\%) - Lender's adjusted cost of bond $(\%)$

\begin{tabular}{lrlr|rll|ll}
\hline & \multicolumn{3}{c|}{ SOE lender } & \multicolumn{3}{c|}{ Non-SOE lender } & \multicolumn{2}{c}{ SOE versus Non-SOE } \\
\hline & $N$ & Mean & Median & \multicolumn{1}{|c}{ N } & Mean & Median & Mean & Median \\
\hline Affiliated loan & 698 & $1.78^{* * *}$ & $1.60^{* * *}$ & 154 & $1.60^{* * *}$ & $1.24 * * *$ & 0.18 & 0.36 \\
Nonaffiliated loan & 80 & $9.86^{* * *}$ & $10.17^{* * *}$ & 42 & $8.95^{* * *}$ & $9.05^{* * *}$ & 0.91 & 1.12 \\
\hline
\end{tabular}




\section{Table 6}

Industry and geographic distributions of entrusted loans

Panel A shows the amount of loans (in billions of RMB) by lender and borrower industries. Panel B shows the amount of lending and borrowing by province or area. All values are in billions of constant year 2013 RMBs. The sample includes 2,960 entrusted loans during the period 2004-2013. We exclude 35 entrusted loans ( 5.8 billion RMB) with unknown borrowers.

Panel A: Industry distribution

\begin{tabular}{lrrr|rrr}
\hline & \multicolumn{3}{c|}{ Lenders } & \multicolumn{3}{c}{ Borrowers } \\
\cline { 2 - 7 } & $\begin{array}{r}\text { All } \\
\text { sample }\end{array}$ & $\begin{array}{c}\text { Nonaffiliated } \\
\text { loans }\end{array}$ & $\begin{array}{c}\text { Affiliated } \\
\text { Loans }\end{array}$ & \multicolumn{1}{c}{$\begin{array}{c}\text { All } \\
\text { sample }\end{array}$} & $\begin{array}{c}\text { Nonaffiliated } \\
\text { loans }\end{array}$ & $\begin{array}{c}\text { Affiliated } \\
\text { loans }\end{array}$ \\
\hline Agriculture & 0.5 & 0.5 & 0.0 & 1.3 & 0.6 & 0.7 \\
Auto \& auto parts & 48.7 & 1.9 & 46.8 & 46.4 & 0.4 & 46.0 \\
Building materials & 9.2 & 0.2 & 9.0 & 10.7 & 1.7 & 9.0 \\
Chemicals & 25.5 & 5.0 & 20.5 & 21.2 & 1.1 & 20.1 \\
Coal \& mining & 248.9 & 1.8 & 247.1 & 257.6 & 0.7 & 256.9 \\
Commerce & 16.8 & 9.3 & 7.5 & 4.5 & 1.8 & 2.7 \\
Conglomerate & 7.8 & 0.6 & 7.2 & 11.8 & 8.6 & 3.2 \\
Culture \& media & 5.0 & 2.9 & 2.1 & 0.3 & 0.2 & 0.1 \\
Education, finance, and others & 0.0 & 0.0 & 0.0 & 2.0 & 1.0 & 1.0 \\
Electrical household appliances & 3.5 & 1.7 & 1.8 & 2.5 & 0.6 & 1.9 \\
Electronics \& IT & 10.4 & 4.0 & 6.4 & 5.8 & 0.8 & 5.0 \\
Food & 11.7 & 1.0 & 10.7 & 10.7 & 0.3 & 10.4 \\
Hotel \& tourism & 1.1 & 0.3 & 0.8 & 4.5 & 2.5 & 2.0 \\
Machinery & 14.9 & 1.6 & 13.3 & 13.5 & 0.9 & 12.6 \\
Nonferrous metal & 4.7 & 1.6 & 3.1 & 6.6 & 0.1 & 6.5 \\
Other light industry & 1.1 & 0.7 & 0.4 & 0.3 & 0.3 & 0.0 \\
Paper \& printing & 7.6 & 0.3 & 7.3 & 7.2 & 0.3 & 6.9 \\
Pharmacy & 11.5 & 1.4 & 10.1 & 9.7 & 0.3 & 9.4 \\
Real estate \& construction & 53.1 & 4.2 & 48.9 & 99.7 & 21.9 & 77.8 \\
Steel & 12.1 & 0.2 & 11.9 & 4.3 & 0.4 & 3.9 \\
Textile \& garment & 6.8 & 2.6 & 4.2 & 2.3 & 0.1 & 2.2 \\
Transportation & 38.5 & 3.5 & 35.0 & 31.5 & 2.7 & 28.8 \\
Utility & 146.6 & 2.2 & 144.4 & 131.6 & 0.2 & 131.4 \\
\hline Total & 686.0 & 47.5 & 638.5 & 686.0 & 47.5 & 638.5 \\
\hline
\end{tabular}




\begin{tabular}{|c|c|c|c|c|c|c|}
\hline \multicolumn{7}{|c|}{ Panel B: Geographic distribution } \\
\hline \multirow[b]{2}{*}{ Province/Area } & \multicolumn{3}{|c|}{ Lenders } & \multicolumn{3}{|c|}{ Borrowers } \\
\hline & All sample & $\begin{array}{c}\text { Nonaffiliated } \\
\text { loans }\end{array}$ & $\begin{array}{c}\text { Affiliated } \\
\text { loans }\end{array}$ & All sample & $\begin{array}{c}\text { Nonaffiliated } \\
\text { loans }\end{array}$ & $\begin{array}{c}\text { Affiliated } \\
\text { loans }\end{array}$ \\
\hline Anhui & 8.0 & 2.5 & 5.5 & 10.3 & 2.6 & 7.7 \\
\hline Beijing & 351.9 & 2.7 & 349.2 & 292.8 & 2.9 & 289.9 \\
\hline Chongqing & 2.7 & 2.0 & 0.7 & 5.1 & 1.6 & 3.5 \\
\hline Fujian & 6.7 & 0.3 & 6.4 & 5.0 & 0.7 & 4.3 \\
\hline Gansu & 2.8 & 0.0 & 2.8 & 1.9 & 0.1 & 1.8 \\
\hline Guangdong & 30.5 & 3.3 & 27.2 & 28.9 & 1.9 & 27.0 \\
\hline Guangxi & 5.7 & 0.2 & 5.5 & 6.1 & 1.8 & 4.3 \\
\hline Guizhou & 2.6 & 0.1 & 2.5 & 4.0 & 0.7 & 3.3 \\
\hline Hainan & 0.8 & 0.2 & 0.6 & 2.7 & 0.2 & 2.5 \\
\hline Hebei & 27.6 & 0.5 & 27.1 & 18.9 & 0.7 & 18.2 \\
\hline Heilongjiang & 0.8 & 0.0 & 0.8 & 1.6 & 0.0 & 1.6 \\
\hline Henan & 5.3 & 1.2 & 4.1 & 7.9 & 1.2 & 6.7 \\
\hline Hong Kong & 0.0 & 0.0 & 0.0 & 2.7 & 0.0 & 2.7 \\
\hline Hubei & 5.7 & 1.1 & 4.6 & 11.2 & 1.5 & 9.7 \\
\hline Hunan & 2.1 & 1.9 & 0.2 & 5.8 & 2.1 & 3.7 \\
\hline Inner Mongolia & 0.0 & 0.0 & 0.0 & 34.4 & 0.0 & 34.4 \\
\hline Jiangsu & 16.9 & 4.3 & 12.6 & 39.5 & 4.8 & 34.7 \\
\hline Jiangxi & 0.7 & 0.4 & 0.3 & 4.5 & 0.2 & 4.3 \\
\hline Jilin & 0.9 & 0.2 & 0.7 & 1.3 & 0.0 & 1.3 \\
\hline Liaoning & 3.9 & 0.1 & 3.8 & 10.7 & 0.2 & 10.5 \\
\hline Ningxia & 0.0 & 0.0 & 0.0 & 1.5 & 0.0 & 1.5 \\
\hline Qinghai & 1.0 & 0.1 & 0.9 & 0.8 & 0.2 & 0.6 \\
\hline Shaanxi & 2.5 & 0.0 & 2.5 & 12.0 & 0.3 & 11.7 \\
\hline Shandong & 45.6 & 2.4 & 43.2 & 24.1 & 2.4 & 21.7 \\
\hline Shanghai & 82.4 & 2.9 & 79.5 & 69.5 & 5.3 & 64.2 \\
\hline Shanxi & 2.6 & 0.0 & 2.6 & 9.0 & 0.0 & 9.0 \\
\hline Sichuan & 3.2 & 0.2 & 3.0 & 10.6 & 0.5 & 10.1 \\
\hline Tianjin & 11.6 & 0.5 & 11.1 & 6.5 & 0.3 & 6.2 \\
\hline Tibet & 0.1 & 0.1 & 0.0 & 0.9 & 0.0 & 0.9 \\
\hline Xinjiang & 2.9 & 0.4 & 2.5 & 7.7 & 0.4 & 7.3 \\
\hline Yunnan & 1.5 & 0.3 & 1.2 & 7.1 & 0.4 & 6.7 \\
\hline Zhejiang & 57.0 & 19.6 & 37.4 & 40.1 & 14.5 & 25.6 \\
\hline Foreign borrower & - & - & - & 0.9 & 0.0 & 0.9 \\
\hline Total & 686.0 & 47.5 & 638.5 & 686.0 & 47.5 & 638.5 \\
\hline
\end{tabular}




\section{Table 7}

Descriptive statistics for entrusted loans

The sample includes 2,960 entrusted loans during the period 2004-2013. The number of nonmissing observations for (adjusted) interest rate and maturity are 2,812 and 2,863, respectively. Variable definitions are in Appendix B. All RMB values are adjusted to constant year 2013 RMBs. Financial variables are winsorized at $1 \%$ and $99 \%$. We use $t$-test for differences in means. $* * *, * *$, and $*$ denote the difference is significant at the $1 \%, 5 \%$, and $10 \%$ levels, respectively.

\begin{tabular}{|c|c|c|c|c|}
\hline & All sample & $\begin{array}{c}\text { Nonaffiliated } \\
\text { loan }\end{array}$ & $\begin{array}{l}\text { Affiliated } \\
\text { loan }\end{array}$ & Diff \\
\hline \multicolumn{5}{|l|}{ Loan characteristics } \\
\hline Loan amount (million RMB) & 231.8 & 80.9 & 269.1 & $-188.2^{*}$ \\
\hline Interest rate (\%) & 7.9 & 13.9 & 6.4 & $7.5 * * *$ \\
\hline Adjusted interest rate (\%) & 1.8 & 7.9 & 0.3 & $7.6^{* * *}$ \\
\hline Maturity (Month) & 16.4 & 11.8 & 17.5 & $-5.7 * * *$ \\
\hline Collateral or Guarantee (\%) & 23.9 & 74.1 & 11.4 & $62.7 * * *$ \\
\hline Collateral (\%) & 18.0 & 55.4 & 8.8 & $46.6^{* * *}$ \\
\hline Guarantee (\%) & 15.0 & 55.7 & 5.0 & $50.7 * * *$ \\
\hline Purpose of loan-debt retirement dummy (\%) & 2.4 & 0.0 & 3.0 & $-3.0 * * *$ \\
\hline Purpose of loan-specified project dummy (\%) & 5.2 & 3.1 & 5.8 & $-2.7 * * *$ \\
\hline \multicolumn{5}{|l|}{ Borrower characteristics } \\
\hline Same city $(\%)$ & 38.8 & 51.3 & 35.7 & $15.6 * * *$ \\
\hline Same industry (\%) & 66.5 & 9.7 & 80.6 & $-70.9 * * *$ \\
\hline SOE borrower (\%) & 66.3 & 19.9 & 77.8 & $-57.9 * * *$ \\
\hline Real estate borrower (\%) & 21.8 & 46.0 & 15.8 & $30.2 * * *$ \\
\hline Borrower industry return volatility high & 53.1 & 66.2 & 49.8 & $16.4 * * *$ \\
\hline Borrower industry sales growth dispersion high & 50.5 & 67.0 & 46.4 & $20.6 * * *$ \\
\hline \multicolumn{5}{|l|}{ Lender characteristics } \\
\hline SOE lender (\%) & 79.5 & 64.1 & 83.3 & $-19.2 * * *$ \\
\hline Real estate lender (\%) & 8.4 & 4.9 & 9.3 & $-4.4 * * *$ \\
\hline Assets (billion RMB) & 34.8 & 13.3 & 40.1 & $-26.8 * * *$ \\
\hline Debt/assets (\%) & 22.9 & 16.0 & 24.5 & $-8.5 * * *$ \\
\hline Change of debt (\%) & 7.9 & 5.2 & 8.6 & $-3.4 * * *$ \\
\hline$N$ & 2,960 & 587 & 2,373 & \\
\hline
\end{tabular}




\section{Table 8}

Adjusted interest rate of nonaffiliated loans versus affiliated loans

This table compares the mean adjusted interest rates between subsamples of loans differing in borrower risk measures. The sample includes 2,812 entrusted loans that have interest rate information during the period 2004-2013. Variable definitions are in Appendix B. We use $t$-test for differences in means. ***, **, and $*$ denote the difference is significant at the $1 \%, 5 \%$, and $10 \%$ levels, respectively.

\begin{tabular}{lccc|ccc}
\hline & \multicolumn{3}{c|}{ Nonaffiliated loans } & \multicolumn{3}{c}{ Affiliated loans } \\
\cline { 2 - 7 } & Yes & No & Diff & Yes & No & Diff \\
\hline Same city & 7.2 & 8.6 & $-1.4^{* * *}$ & 0.2 & 0.4 & $-0.2^{*}$ \\
Same industry & 6.0 & 8.1 & $-2.1^{* * *}$ & 0.1 & 1.3 & $-1.2^{* * *}$ \\
SOE Borrower & 4.2 & 8.8 & $-4.6^{* * *}$ & 0.2 & 0.7 & $-0.5^{* * *}$ \\
Real estate borrower & 9.5 & 6.6 & $2.9^{* * *}$ & 2.8 & -0.2 & $3.0^{* * *}$ \\
Borrower industry return volatility high & 9.0 & 6.7 & $2.3^{* * *}$ & 0.5 & 0.1 & $0.4^{* * *}$ \\
Borrower industry sales growth dispersion high & 8.5 & 6.8 & $1.7^{* * *}$ & 0.8 & -0.2 & $1.0^{* * *}$ \\
\hline
\end{tabular}




\section{Table 9}

Determinants of interest rates of entrusted loans

The sample includes 2,808 entrusted loans for which the information of interest rate and maturity are available during the period 2004-2013. Variable definitions are in Appendix B. Financial variables are winsorized at $1 \%$ and $99 \%$. $p$-values are based on standard errors double-clustered by firm and year. $* * *$, $* *$, and $*$ denote significance at the $1 \%, 5 \%$, and $10 \%$ levels, respectively.

\begin{tabular}{|c|c|c|c|c|}
\hline \multicolumn{5}{|l|}{ Panel A: Nonaffiliated loans } \\
\hline Adjusted interest rate (\%) & (1) & (2) & (3) & (4) \\
\hline \multicolumn{5}{|l|}{ Loan characteristics } \\
\hline Maturity (Month) & $\begin{array}{l}-0.13 * * * \\
(0.00)\end{array}$ & $\begin{array}{l}-0.14 * * * \\
(0.00)\end{array}$ & $\begin{array}{l}-0.15 * * * \\
(0.00)\end{array}$ & $\begin{array}{l}-0.11 \text { *** } \\
(0.01)\end{array}$ \\
\hline Collateral or Guarantee & $\begin{array}{l}2.40 * * \\
(0.02)\end{array}$ & $\begin{array}{l}2.36^{* *} \\
(0.02)\end{array}$ & $\begin{array}{l}2.40^{* * *} \\
(0.01)\end{array}$ & $\begin{array}{l}2.36^{* * * *} \\
(0.01)\end{array}$ \\
\hline Purpose of loan-specified project dummy & $\begin{array}{l}-0.74 \\
(0.42)\end{array}$ & $\begin{array}{l}-0.84 \\
(0.34)\end{array}$ & $\begin{array}{l}-0.79 \\
(0.31)\end{array}$ & $\begin{array}{l}-0.41 \\
(0.66)\end{array}$ \\
\hline \multicolumn{5}{|l|}{ Borrower characteristics } \\
\hline Same city & $\begin{array}{l}-1.39 * * * \\
(0.01)\end{array}$ & $\begin{array}{l}-1.41 * * * \\
(0.01)\end{array}$ & $\begin{array}{l}-1.62 * * * \\
(0.00)\end{array}$ & $\begin{array}{l}-0.89 \\
(0.12)\end{array}$ \\
\hline Same industry & $\begin{array}{l}-2.11 * * * \\
(0.00)\end{array}$ & $\begin{array}{l}-1.77 * * \\
(0.02)\end{array}$ & $\begin{array}{l}-1.56^{* *} \\
(0.04)\end{array}$ & $\begin{array}{l}-2.03 * * * \\
(0.00)\end{array}$ \\
\hline Borrower industry return volatility high & $\begin{array}{l}1.03 \text { *** } \\
(0.01)\end{array}$ & & & \\
\hline Borrower industry sales growth dispersion high & & $\begin{array}{l}1.36^{* * * *} \\
(0.00)\end{array}$ & & \\
\hline Real estate borrower & & & $\begin{array}{l}2.50 * * * \\
(0.00)\end{array}$ & \\
\hline SOE borrower & & & & $\begin{array}{l}-3.05^{* * *} \\
(0.00)\end{array}$ \\
\hline \multicolumn{5}{|l|}{ Lender characteristics } \\
\hline SOE lender & $\begin{array}{r}0.84 \\
(0.15)\end{array}$ & $\begin{array}{r}0.80 \\
(0.15)\end{array}$ & $\begin{array}{c}0.91 \\
(0.11)\end{array}$ & $\begin{array}{r}0.75 \\
(0.17)\end{array}$ \\
\hline Ln (assets) & $\begin{array}{r}0.19 \\
(0.60)\end{array}$ & $\begin{array}{r}0.20 \\
(0.58)\end{array}$ & $\begin{array}{c}0.15 \\
(0.63)\end{array}$ & $\begin{array}{r}0.27 \\
(0.43)\end{array}$ \\
\hline Debt/assets (\%) & $\begin{array}{l}0.06^{* * *} \\
(0.05)\end{array}$ & $\begin{array}{l}0.06^{* *} \\
(0.04)\end{array}$ & $\begin{array}{l}0.06^{* * *} \\
(0.02)\end{array}$ & $\begin{array}{r}0.05 \\
(0.12)\end{array}$ \\
\hline Change of debt (\%) & $\begin{array}{l}0.04 * * * \\
(0.01)\end{array}$ & $\begin{array}{l}0.04 * * * \\
(0.00)\end{array}$ & $\begin{array}{c}0.04 * * \\
(0.03)\end{array}$ & $\begin{array}{l}0.04^{* * * *} \\
(0.01)\end{array}$ \\
\hline Year fixed effect & Yes & Yes & Yes & Yes \\
\hline Industry fixed effect & Yes & Yes & Yes & Yes \\
\hline$N$ & 566 & 566 & 566 & 566 \\
\hline $\operatorname{Adj} R^{2}$ & 0.46 & 0.46 & 0.50 & 0.49 \\
\hline
\end{tabular}




\begin{tabular}{|c|c|c|c|c|}
\hline \multicolumn{5}{|l|}{ Panel B: Affiliated loans } \\
\hline Adjusted interest rate (\%) & (1) & (2) & (3) & (4) \\
\hline \multicolumn{5}{|l|}{ Loan characteristics } \\
\hline Maturity (Month) & $\begin{array}{r}-0.006 \\
(0.25)\end{array}$ & $\begin{array}{r}-0.006 \\
(0.26)\end{array}$ & $\begin{array}{r}-0.006 \\
(0.22)\end{array}$ & $\begin{array}{r}-0.007 \\
(0.22)\end{array}$ \\
\hline Collateral or Guarantee & $\begin{array}{l}0.67 * * * \\
(0.01)\end{array}$ & $\begin{array}{l}0.70^{* * *} \\
(0.01)\end{array}$ & $\begin{array}{l}0.75 * * * \\
(0.00)\end{array}$ & $\begin{array}{l}0.64 * * * \\
(0.01)\end{array}$ \\
\hline Purpose of loan-debt retirement dummy & $\begin{array}{l}-0.16 \\
(0.17)\end{array}$ & $\begin{array}{l}-0.07 \\
(0.55)\end{array}$ & $\begin{array}{r}0.04 \\
(0.66)\end{array}$ & $\begin{array}{l}-0.10 \\
(0.41)\end{array}$ \\
\hline Purpose of loan-specified project dummy & $\begin{array}{l}-0.81 * * \\
(0.03)\end{array}$ & $\begin{array}{l}-0.81^{* *} \\
(0.03)\end{array}$ & $\begin{array}{l}-0.63^{*} \\
(0.06)\end{array}$ & $\begin{array}{l}-0.82 * * \\
(0.04)\end{array}$ \\
\hline \multicolumn{5}{|l|}{ Borrower characteristics } \\
\hline Same city & $\begin{array}{l}-0.39 * * \\
(0.05)\end{array}$ & $\begin{array}{l}-0.38^{* *} \\
(0.05)\end{array}$ & $\begin{array}{l}-0.43 * * \\
(0.02)\end{array}$ & $\begin{array}{l}-0.34 * \\
(0.07)\end{array}$ \\
\hline Same industry & $\begin{array}{l}-0.70 * * \\
(0.02)\end{array}$ & $\begin{array}{l}-0.74^{* * *} \\
(0.01)\end{array}$ & $\begin{array}{l}-0.22 \\
(0.14)\end{array}$ & $\begin{array}{l}-0.76^{* * *} \\
(0.01)\end{array}$ \\
\hline Borrower industry return volatility high & $\begin{array}{l}0.55^{* * *} \\
(0.01)\end{array}$ & & & \\
\hline Borrower industry sales growth dispersion high & & $\begin{array}{l}0.42^{* * *} \\
(0.01)\end{array}$ & & \\
\hline Real estate borrower & & & $\begin{array}{l}2.71 * * * \\
(0.00)\end{array}$ & \\
\hline SOE borrower & & & & $\begin{array}{l}-0.59 \\
(0.23)\end{array}$ \\
\hline Ownership & $\begin{array}{l}-1.11 * * * \\
(0.00)\end{array}$ & $\begin{array}{l}-1.12^{* * *} \\
(0.00)\end{array}$ & $\begin{array}{l}-1.12 * * * \\
(0.00)\end{array}$ & $\begin{array}{l}-1.06 * * * \\
(0.00)\end{array}$ \\
\hline Trade relationship & $\begin{array}{l}-1.45 * * * \\
(0.00)\end{array}$ & $\begin{array}{l}-1.54^{* * * *} \\
(0.00)\end{array}$ & $\begin{array}{l}-1.31 * * * \\
(0.01)\end{array}$ & $\begin{array}{l}-1.78 * * * \\
(0.00)\end{array}$ \\
\hline \multicolumn{5}{|l|}{ Lender characteristics } \\
\hline SOE lender & $\begin{array}{l}-0.14 \\
(0.53)\end{array}$ & $\begin{array}{l}-0.11 \\
(0.60)\end{array}$ & $\begin{array}{l}-0.05 \\
(0.82)\end{array}$ & $\begin{array}{r}0.33 \\
(0.47)\end{array}$ \\
\hline Ln (assets) & $\begin{array}{l}-0.31 * * * \\
(0.00)\end{array}$ & $\begin{array}{l}-0.30^{* * *} \\
(0.00)\end{array}$ & $\begin{array}{l}-0.30 * * * \\
(0.00)\end{array}$ & $\begin{array}{l}-0.30 * * * \\
(0.00)\end{array}$ \\
\hline Debt/assets (\%) & $\begin{array}{r}0.01 \\
(0.22)\end{array}$ & $\begin{array}{r}0.01 \\
(0.25)\end{array}$ & $\begin{array}{r}0.01 \\
(0.38)\end{array}$ & $\begin{array}{r}0.01 \\
(0.25)\end{array}$ \\
\hline Change of debt (\%) & $\begin{array}{l}0.02 * * * \\
(0.00)\end{array}$ & $\begin{array}{l}0.02^{* * * *} \\
(0.00)\end{array}$ & $\begin{array}{l}0.02 * * * \\
(0.00)\end{array}$ & $\begin{array}{l}0.02 * * * \\
(0.00)\end{array}$ \\
\hline $\begin{array}{l}\text { Year fixed effect } \\
\text { Industry fixed effect }\end{array}$ & $\begin{array}{l}\text { Yes } \\
\text { Yes }\end{array}$ & $\begin{array}{l}\text { Yes } \\
\text { Yes }\end{array}$ & $\begin{array}{l}\text { Yes } \\
\text { Yes }\end{array}$ & $\begin{array}{l}\text { Yes } \\
\text { Yes }\end{array}$ \\
\hline$N$ & 2,225 & 2,225 & 2,225 & 2,225 \\
\hline $\operatorname{Adj} R^{2}$ & 0.35 & 0.34 & 0.41 & 0.34 \\
\hline
\end{tabular}




\section{Table 10}

Performance of entrusted loans

The sample includes 2,243 entrusted loans during the period 2004-2013. We exclude loans that are not due by the end of year 2013. RMB values are adjusted to constant year $2013 \mathrm{RMBs}$. We use $t$-test for differences in means. $* * *, * *$, and $*$ denote the difference is significant at the $1 \%, 5 \%$, and $10 \%$ levels, respectively.

\begin{tabular}{lcccc}
\hline Panel A: Frequency of loan delinquency or extension or overdue & & \\
\hline & $\begin{array}{c}\text { All } \\
\text { sample }\end{array}$ & $\begin{array}{c}\text { Nonaffiliated } \\
\text { loans }\end{array}$ & $\begin{array}{c}\text { Affiliated } \\
\text { loans }\end{array}$ & $\begin{array}{c}\text { Average loan amount } \\
\text { (million RMB) }\end{array}$ \\
\hline Delinquency due to borrower bankruptcy & 3 & 0 & 3 & 50.8 \\
Overdue & 32 & 19 & 13 & 98.8 \\
Extended (on average by 11 months) & 159 & 45 & 114 & 138.6 \\
Total & 194 & 64 & 130 & \\
& $(8.6 \%)$ & $(13.9 \%)$ & $(7.3 \%)$ & \\
\hline
\end{tabular}

\begin{tabular}{llllllll}
\hline \multicolumn{7}{l}{ Panel B: Adjusted interest rates (\%) for nonproblematic loans versus problematic loans } \\
\hline & $(1)$ & $(2)$ & $(3)$ & $(4)$ & & & \\
& Delinquent & Overdue & Extended & Nonproblematic & $(1)-(4)$ & $(2)-(4)$ & $(3)-(4)$ \\
& loans & loans & loans & loans & & & \\
\hline Nonaffiliated loan & n/a & 10.2 & 10.9 & 7.8 & $\mathrm{n} / \mathrm{a}$ & $2.4^{*}$ & $3.1^{* * *}$ \\
Affiliated loan & 0.5 & -0.1 & 0.6 & 0.3 & 0.2 & -0.4 & 0.3 \\
All sample & 0.5 & 6.1 & 3.5 & 1.8 & -1.3 & $4.3^{* * *}$ & $1.7^{* * *}$ \\
\hline
\end{tabular}




\section{Table 11}

Determinants of loan performance: Logistic regressions

The sample includes 440 nonaffiliated loans and 1,636 affiliated loans for which the information of interest rate, maturity, and ownership are available during the period 2004-2013. We exclude loans that are not due by the end of 2013. Variable definitions are in Appendix B. Financial variables are winsorized at $1 \%$ and $99 \%$. $p$-values are based on standard errors double-clustered by firm and year. ***, **, and * denote significance at the $1 \%, 5 \%$, and $10 \%$ levels, respectively. 


\section{Table 12}

Market reaction to entrusted loan announcements

The cumulative abnormal return (CAR) is calculated based on the market model, where the index return of stocks traded on Shanghai and Shenzhen stock exchanges is used as the market proxy and the estimation period is during trading days $[-150,-10]$, where day 0 is the announcement day. Variable definitions are in Appendix B. Financial variables are winsorized at $1 \%$ and $99 \%$. We use $t$-test for differences in means. $* * *, * *$, and $*$ denote the difference is significant at the $1 \%, 5 \%$, and $10 \%$ levels, respectively. $p$-values are based on standard errors double clustered by firm and year.

\begin{tabular}{lccc}
\hline Panel A: Univariate analysis & & & \\
\hline & $C A R[-1,+1](\%)$ & $C A R[-3,+3](\%)$ & $C A R[-5,+5](\%)$ \\
\hline Affiliated loans $(n=358)$ & 0.16 & 0.34 & 0.47 \\
A firm's first announcement $(n=134)$ & 0.47 & 0.87 & $1.36^{*}$ \\
Subsequent announcements $(n=224)$ & -0.02 & 0.02 & -0.06 \\
Difference & 0.49 & 0.85 & 1.42 \\
\hline Nonaffiliated loans $(n=189)$ & $-0.73^{* *}$ & $-1.26^{* *}$ & $-1.39^{*}$ \\
A firm's first announcement $(n=79)$ & $-1.62^{* * *}$ & $-2.78^{* * *}$ & $-3.78^{* * *}$ \\
Subsequent announcements $(n=110)$ & -0.10 & -0.17 & 0.33 \\
Difference & $-1.52^{* *}$ & $-2.61^{* * *}$ & $-4.11^{* * *}$ \\
\hline
\end{tabular}

\begin{tabular}{|c|c|c|c|c|}
\hline \multicolumn{5}{|l|}{ Panel B: Regressions } \\
\hline \multirow{2}{*}{$C A R[-5,+5](\%)$} & \multicolumn{2}{|c|}{ Nonaffiliated loans } & \multicolumn{2}{|c|}{ Affiliated loans } \\
\hline & OLS & Heckman 2nd stage & OLS & Heckman 2nd stage \\
\hline A firm's first announcement & $\begin{array}{l}-4.94 * * * \\
(0.00)\end{array}$ & $\begin{array}{l}-4.89 * * * \\
(0.00)\end{array}$ & $\begin{array}{l}1.62^{* * *} \\
(0.00)\end{array}$ & $\begin{array}{r}1.51 \\
(0.12)\end{array}$ \\
\hline Ln (loan amount) & $\begin{array}{l}-0.04 \\
(0.94)\end{array}$ & $\begin{array}{r}0.02 \\
(0.98)\end{array}$ & $\begin{array}{l}-0.44 \\
(0.24)\end{array}$ & $\begin{array}{l}-0.47 \\
(0.21)\end{array}$ \\
\hline Adjusted interest rate (\%) & $\begin{array}{l}-0.28 \\
(0.16)\end{array}$ & $\begin{array}{l}-0.27 \\
(0.16)\end{array}$ & $\begin{array}{r}0.22 \\
(0.56)\end{array}$ & $\begin{array}{r}0.21 \\
(0.26)\end{array}$ \\
\hline Maturity (Month) & $\begin{array}{l}-0.05 \\
(0.59)\end{array}$ & $\begin{array}{l}-0.05 \\
(0.68)\end{array}$ & $\begin{array}{l}0.04 * * \\
(0.03)\end{array}$ & $\begin{array}{r}0.04 \\
(0.25)\end{array}$ \\
\hline Collateral or Guarantee & $\begin{array}{l}-2.07 \\
(0.48)\end{array}$ & $\begin{array}{l}-2.00 \\
(0.42)\end{array}$ & $\begin{array}{l}-0.42 \\
(0.53)\end{array}$ & $\begin{array}{l}-0.50 \\
(0.63)\end{array}$ \\
\hline Inverse Mills Ratio & & $\begin{array}{r}0.62 \\
(0.79)\end{array}$ & & $\begin{array}{l}-0.55 \\
(0.75)\end{array}$ \\
\hline Adj $R 2$ & 0.06 & & 0.02 & \\
\hline$N$ & 189 & & 353 & \\
\hline & & Heckman 1st stage & & Heckman 1st stage \\
\hline Ln (loan amount) & & $\begin{array}{l}0.46^{* * *} \\
(0.00)\end{array}$ & & $\begin{array}{l}0.19 * * * \\
(0.00)\end{array}$ \\
\hline Ln (assets) & & $\begin{array}{l}-0.67 * * * \\
(0.00)\end{array}$ & & $\begin{array}{l}-0.32 * * * \\
(0.00)\end{array}$ \\
\hline$R O A(\%)$ & & $\begin{array}{l}-0.02 * * \\
(0.05)\end{array}$ & & $\begin{array}{r}-0.003 \\
(0.65)\end{array}$ \\
\hline Debt/assets (\%) & & $\begin{array}{r}-0.001 \\
(0.76)\end{array}$ & & $\begin{array}{r}0.002 \\
(0.48)\end{array}$ \\
\hline SOE lender & & $\begin{array}{l}-0.03 \\
(0.82)\end{array}$ & & $\begin{array}{l}-0.18 * * \\
(0.03)\end{array}$ \\
\hline Wald chi2 & & 56.8 & & 64.9 \\
\hline Sigma & & 9.71 & & 8.34 \\
\hline$N$ & & 587 & & 2,373 \\
\hline
\end{tabular}


Figure 1. Geographic distribution of lending and borrowing

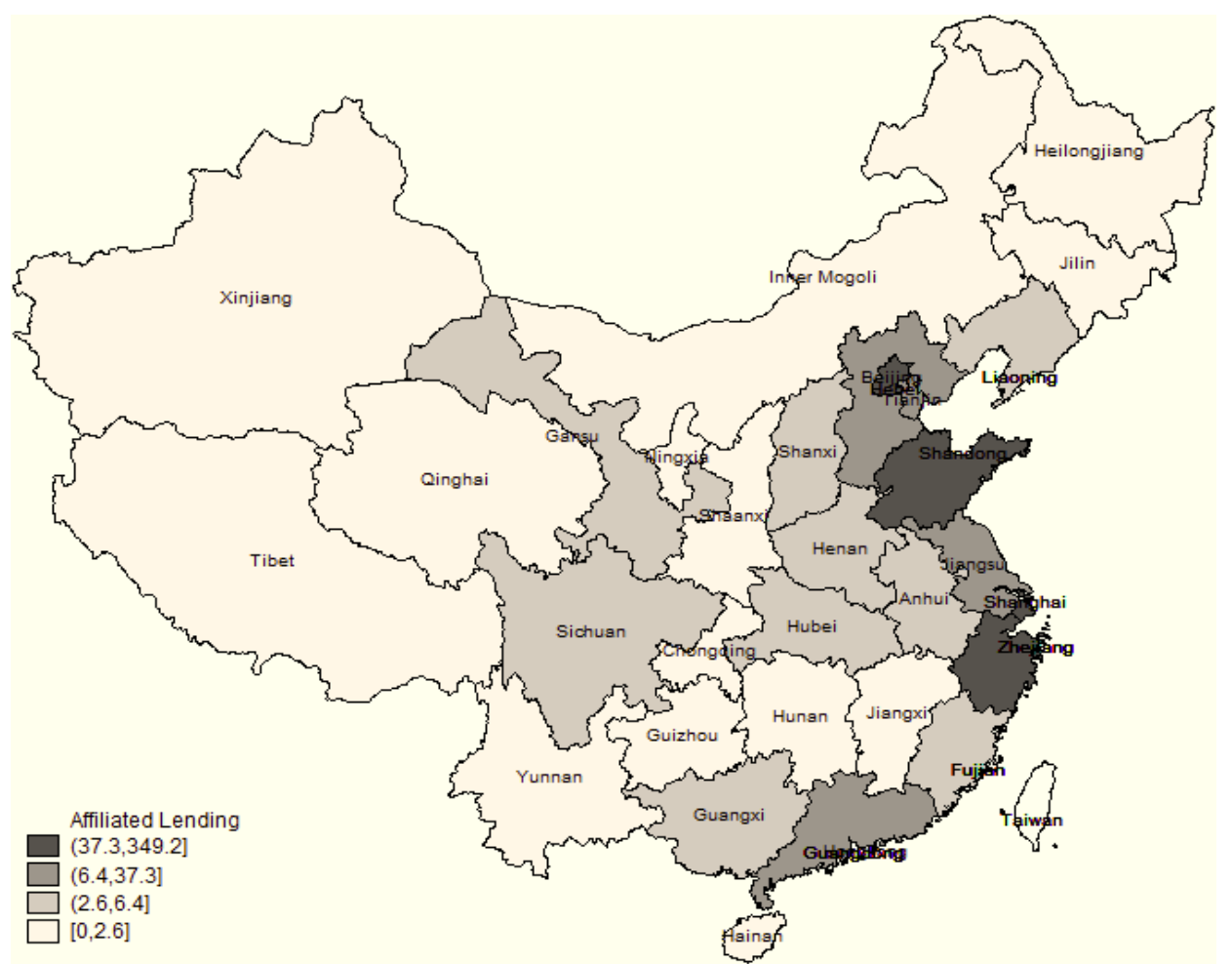

Figure 1.1 The map of affiliated lending

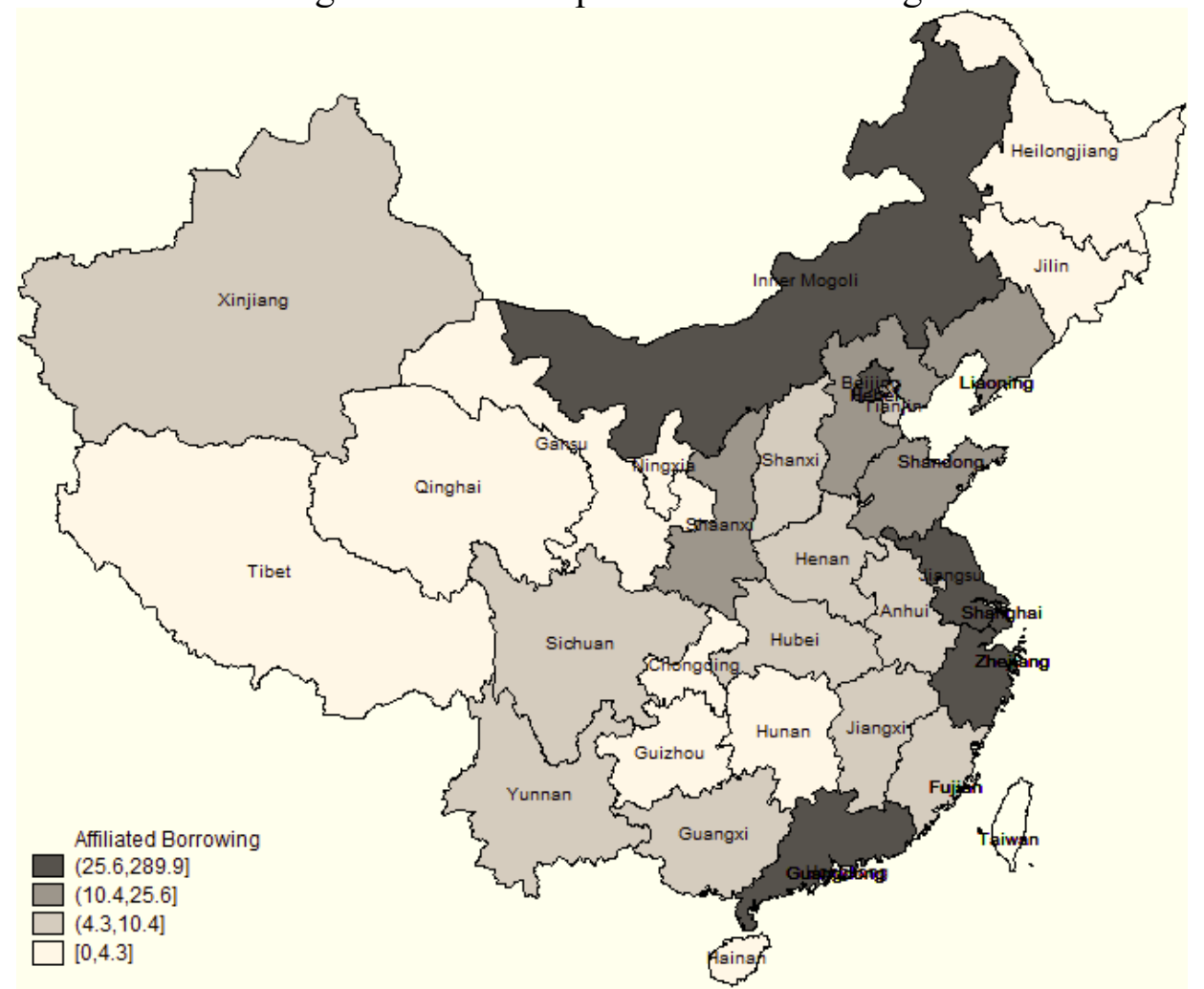

Figure 1.2 The map of affiliated borrowing 


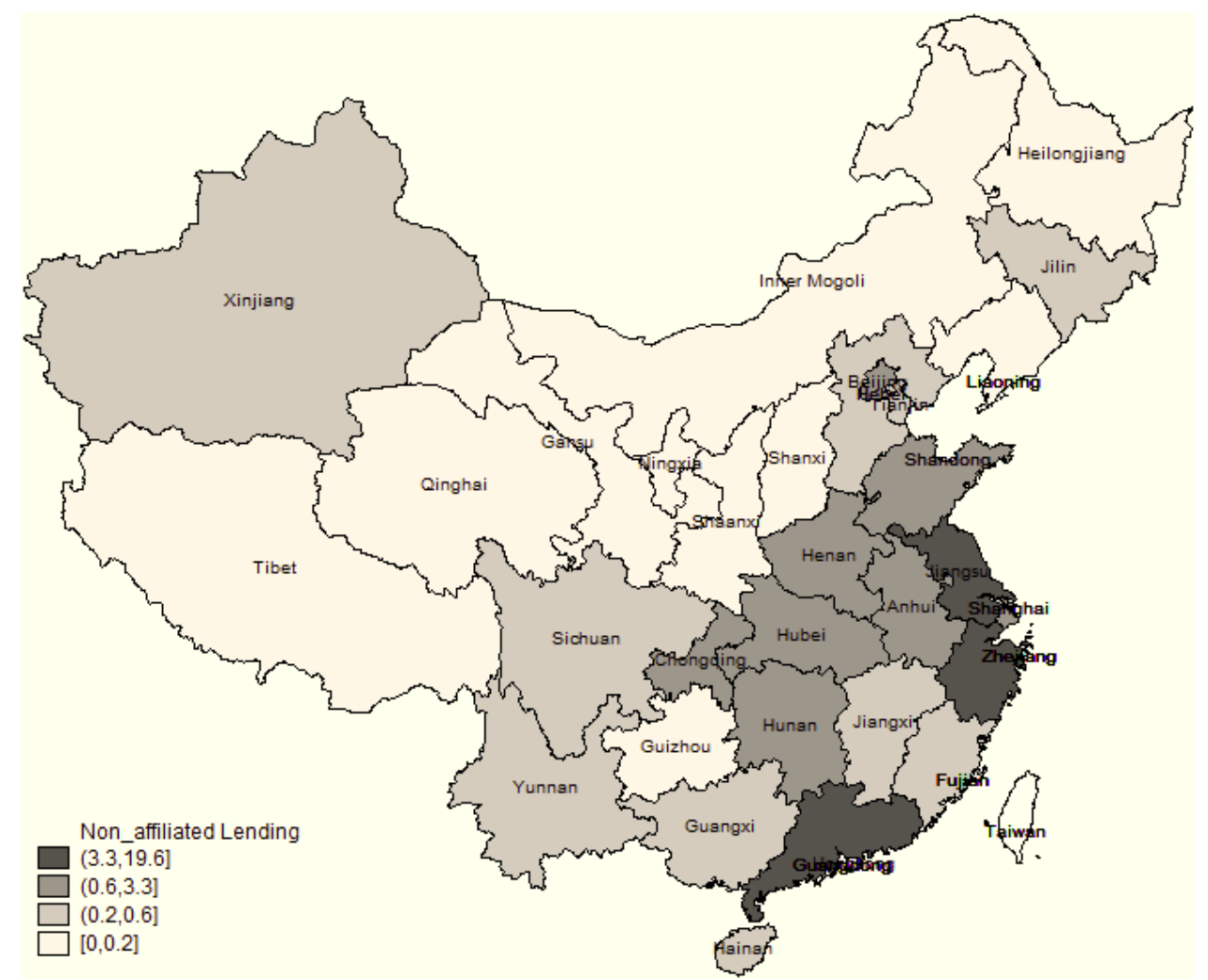

Figure 1.3 The map of nonaffiliated lending

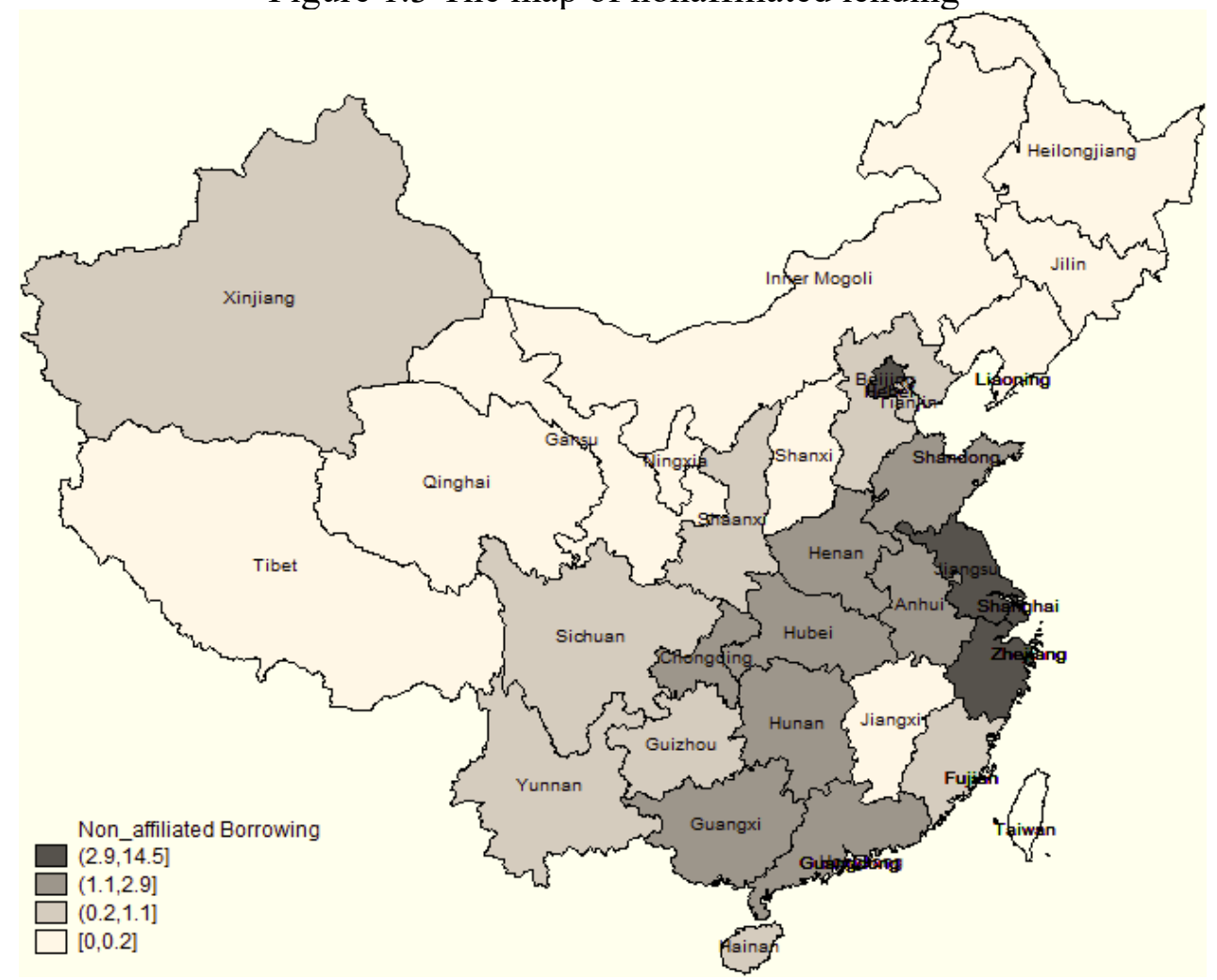

Figure 1.4 The map of nonaffiliated borrowing 